\title{
Effect of single post-ovulatory administration of mifepristone (RU486) on transcript profile during the receptive period in human endometrium
}

\author{
Catherina A Cuevas, Alejandro Tapia-Pizarro ${ }^{1}$, Ana María Salvatierra ${ }^{2}$, David J Munroe ${ }^{3}$, \\ Luis Velasquez ${ }^{4}$ and Horacio B Croxatto ${ }^{4}$ \\ Universidad de Santiago de Chile, Santiago, Chile, ${ }^{1}$ Institute for Maternal and Child Research (IDIMI), Universidad de \\ Chile, Correo 226-3 Santiago, Chile, ${ }^{2}$ Instituto Chileno de Medicina Reproductiva (ICMER), Santiago, Chile, \\ ${ }^{3}$ Laboratory of Molecular Technology, National Cancer Institute-Science Applications International Corporation, \\ Frederick, Maryland, USA and ${ }^{4}$ Facultad de Medicina, Center for Integrative Medicine and Innovative Science \\ (CIMIS), Universidad Andres Bello, Santiago, Chile
}

Correspondence should be addressed to A Tapia-Pizarro; Email: atapiap@med.uchile.cl

\begin{abstract}
Progesterone regulates uterine function during the luteal phase and is essential for the acquisition of endometrial receptivity. The objective of the present study was to identify endometrial transcripts whose expression is altered during the window of implantation after the administration of $\mathbf{2 0 0} \mathrm{mg}$ of the antiprogestin mifepristone, $48 \mathrm{~h}$ after the $\mathrm{LH}$ peak $(\mathrm{LH}+\mathbf{2}, \mathrm{LH}+\mathbf{0}=\mathrm{LH}$ peak), and to determine the relationship of these transcripts with those regulated during the acquisition of receptivity. Endometrial samples were obtained in LH +7 from seven women of proven fertility, each one contributing with one cycle treated with placebo and another with mifepristone. Additionally, endometrial samples were obtained in $\mathrm{LH}+2$ and $\mathrm{LH}+7$ during a single untreated spontaneous cycle from seven normal fertile women as a reference. DNA microarrays were used to identify transcripts significantly regulated (defined as $\geq 2.0$-fold change with false discovery rate below $1 \%$ using $t$-test) with the administration of mifepristone vs placebo, or during the transition from pre-receptive to receptive $(\mathrm{LH}+2 \mathrm{vs} \mathrm{LH}+7)$. Approximately 2000 transcripts were significantly regulated in both comparisons (mifepristone vs placebo and $\mathbf{L H}+2$ vs $\mathbf{L H}+7$ ), but only 777 of them were coincident and displayed opposite regulation except for 25 . The mRNA level for eight selected genes regulated by mifepristone was confirmed by real-time RT-PCR. We conclude that not all changes in endometrial transcript levels occurring in the transition from $\mathrm{LH}+2$ to $\mathrm{LH}+7$ seem to be regulated by the progesterone receptor and $\sim 37 \%$ of the genes whose transcript levels changed by effect of mifepristone could be associated with the acquisition of receptivity.

Reproduction (2016) $151331-349$
\end{abstract}

\section{Introduction}

Human endometrium displays characteristic morphological and molecular changes during each stage of development during menstrual cycle under the control of the ovarian hormones estradiol and progesterone $\left(\mathrm{P}_{4}\right)$. Both epithelial and stromal cells undergo mitosis in response to rising estradiol serum levels during the proliferative phase of the endometrial cycle whereas the secretory phase is driven by $\mathrm{P}_{4}$ (Bagchi et al. 2003), which triggers a highly coordinated and sequential responses beginning with the suppression of the estrogen-dependent epithelial cell proliferation and inducing endometrial differentiation and maturation characterized by the secretory transformation of the glands, infiltration of immune cells and stromal edema (Strowitzki et al. 2006, Gellersen et al. 2007). At functional level, $\mathrm{P}_{4}$ renders the uterus in an adequate morphological and functional state for embryo implantation during a self-limited time (Paria et al. 2002). This period, so-called window of implantation, lasts for $\sim 5$ days starting on day 20 (day $\mathrm{LH}+7-11$ ) of a 28-days menstrual cycle (Navot et al. 1991, Wilcox et al. 1999). On target cells, $\mathrm{P}_{4}$ exerts its effects primarily through the nuclear $\mathrm{P}_{4}$ receptor (PGR) (Tsai \& O'Malley 1994), a member of the superfamily of ligand-activated transcription factors (Misrahi et al. 1987). PGR is a ligand activated transcription factor (Chabbert-Buffet et al. 2005) which upon $P_{4}$ binding activates its gene regulatory functions (Graham \& Clarke 1997). The hormone-receptor complex interacts with specific target genes, modulating their expression. Two PGR isoforms have been described, PGR-A and PGR-B, which are transcribed from a single gene with two distinct promoters (O'Malley \& Tsai 1992). In addition, $\mathrm{P}_{4}$ may elicit several rapid signaling events, independent of 
transcriptional regulation or even in the absence of its nuclear receptors (Gellersen et al. 2009). It is accepted that these rapid non-genomic signaling events along with the relatively slower genomic actions, determine the functional response to $\mathrm{P}_{4}$ in cell type- and milieuspecific manner. While the genomic responses are better understood, the mechanisms underlying non-genomic $\mathrm{P}_{4}$ actions are mostly yet to be determined (Gellersen et al. 2009).

In the endometrium, $\mathrm{P}_{4}$ regulates the expression and repression of genes during the period of receptivity that eventually induce a physiological state required to initiate and support pregnancy (Tabibzadeh 1998, Wang \& Dey 2006). In women, most of $\mathrm{P}_{4}$-regulated genes in the endometrium that might be relevant in embryo implantation have been identified using DNA microarrays by comparing the endometrial gene expression profile of women during mid-secretory phase (peak circulating $\mathrm{P}_{4}$ ) with proliferative or early secretory phase (low circulating $\mathrm{P}_{4}$ ) in spontaneous cycles. Unfortunately, few genes that were significantly and similarly regulated during the window of implantation have been reported considering the total number of regulated transcripts comprising each list of six different reports (Tapia et al. 2011). Since $P_{4}$ drives endometrial receptivity, chemical compounds that block $\mathrm{P}_{4}$ action interfere with its transition to the secretory phenotype and avoid or interrupt pregnancy. One of this compounds is mifepristone ( $R U 486)$, a synthetic 19 nor-steroid antagonist of the PGR (Spitz 2003) that inhibits $\mathrm{P}_{4}$-mediated gene transcription and, if administered post-implantation, ultimately leads to conceptus abortion (Baulieu 1989). The molecular mechanism of mifepristone action is not completely understood although it has been described that receptor activation, heat shock proteins dissociation, dimerization and binding to $\mathrm{P}_{4}$ response elements in the DNA do not appear to be affected upon mifepristone binding to PGR. This suggests that the interaction and recruitment of corregulators (Liu et al. 2002) are the main factors driving its antiprogestin activity (Chauchereau et al. 2003, Dasgupta \& O'Malley 2014, Szwarc et al. 2015). In addition, mifepristone may act as $\mathrm{P}_{4}$ antagonist for some non-genomic responses elicited by $\mathrm{P}_{4}$ (Chien et al. 2009).

The effects of mifepristone in the endometrium depend on the dose and day of the menstrual cycle it is administered (Gemzell-Danielsson et al. 1993). Its administration during the proliferative phase inhibits follicular development and delays the $\mathrm{LH}$ peak retarding ovulation. Consequently, the menstrual cycle length is extended without effects on endometrial morphology (Liu et al. 1987, Swahn et al. 1988). When mifepristone is administered during the mid or late luteal phase induces endometrial bleeding a few days after its administration (Schaison et al. 1985, Shoupe et al. 1987, Swahn et al. 1988). When a single dose of mifepristone $(200 \mathrm{mg})$ is administered 2 days after ovulation (i.e. 2 days after the $\mathrm{LH}$ surge, $\mathrm{LH}+2$ ) affects neither the menstrual cycle length nor serum estrogen and $\mathrm{P}_{4}$ levels, however it profoundly affects endometrial morphology, retarding endometrial development and inhibiting the glandular secretory activity (Swahn et al. 1990) which ultimately prevents pregnancy (GemzellDanielsson et al. 1993, Hapangama et al. 2001). Gemzell-Danielsson et al. (1993) reported the contraceptive effects of a single dose of mifepristone $200 \mathrm{mg}$ in $\mathrm{LH}+2$ to a group of women as their only contraceptive method. In 124 out of 157 cycles, sexual intercourse occurred during the fertile period and only one pregnancy was documented. Similar results were obtained in other study (Hapangama et al. 2001) using the same administration protocol and dose in which 136 out of 178 studied cycles were ovulatory and exposed, reporting only one pregnancy. Although these studies do not allow a pregnancy rate calculation (Croxatto 2003), they reveal a clear contraceptive effect upon the administration of a single mifepristone dose during the early luteal phase (day $\mathrm{LH}+2$ ). The evidence from the clinical studies and the reported effects on the endometrial morphology provide robust evidence that the changes produced in the endometrium during the receptive phase are enough for preventing embryo implantation. In addition, studies using co-culture of human embryos with in vitro endometrial constructions showed that mifepristone inhibits embryo adhesion to the endometrial layer (Lalitkumar et al. 2007). Mifepristone has been used previously to evaluate endometrial gene expression in vitro using tissue explants obtained during the mid-secretory phase (Catalano et al. 2003). However, this model does not reflex the steroids dynamics occurring in vivo. Tissue explants are appropriate for evaluating immediate responses in human endometrium to ovarian steroids ex vivo but do not fully address the entire set of genes associated to embryo implantation (Catalano et al. 2007, Dassen et al. 2007a). The endometrial response to $200 \mathrm{mg}$ of mifepristone in day $\mathrm{LH}+8$ was evaluated in women after 6 or $24 \mathrm{~h}$ of treatment (Catalano et al. 2007). Although this model was designed to identify $\mathrm{P}_{4}$-regulated genes involved in the endometrial receptivity, also pinpoints transcripts related to the induction of menstruation, introducing a confounding factor in the determination of uterine receptivity genes. The effect of mifepristone administration during the early luteal phase on human endometrial gene expression during the receptive period in vivo has not yet been studied. We hypothesize that the administration of mifepristone on $\mathrm{LH}+2$ will inhibit $\mathrm{P}_{4}$-induced gene expression changes required for endometrial receptivity. Such design does not induces menses prematurely nor alters circulating estrogen and $\mathrm{P}_{4}$ levels, allowing the evaluation of gene expression changes induced by mifepristone in receptive endometrium, under conditions that inhibit implantation without inducing menses. The objective of the present study is 
to identify endometrial genes whose transcript levels on $\mathrm{LH}+7$ is altered upon administration of mifepristone on $\mathrm{LH}+2$ and to determine their relation with the gene expression profile of the endometrium during the transition from pre-receptive $(\mathrm{LH}+2)$ to receptive $(\mathrm{LH}+7)$.

\section{Materials and methods}

\section{Participants}

The present study was conducted using a protocol in accordance with the guidelines in the Declaration of Helsinki and approved by the Ethical and Scientific Review Committee from Instituto Chileno de Medicina Reproductiva (ICMER). Each volunteer signed an informed consent form before participating. Two groups of seven women were recruited for the study, all of them having good health as determined by medical history, physical and gynecological examination. All volunteers were of Hispanic ethnicity, surgically sterilized at least 1 year before participating in the study for reasons unrelated to this study, regular menstrual cycles within the range of 26-35 days. Age, BMI and hemoglobin levels of all participating women are presented in Table 1. No one was under chronic medication or taking hormones or drugs able to modify the metabolism of steroid hormones in the 3 preceding months. Functional and anthropometric and parameters of participating women are presented in Table 1.

\section{Study design}

This study was comprised of two parts. The first one was a placebo controlled, cross-over, double-blinded and randomized trial that included seven volunteers. Each subject contributed with one placebo-treated cycle (control) and one mifepristone-treated cycle (experimental) in a randomized order and one endometrial biopsy was taken on day $\mathrm{LH}+7$ $(\mathrm{LH}+0=$ day of $\mathrm{LH}$ peak) of each cycle. Three women started with the control cycle and the other four with the experimental cycle. The following two cycles, no treatment was given (resting cycles) and no biopsy was taken. At the fourth consecutive cycle, a corresponding swap with experimental and control cycles was done.

In order to control the timing of the interventions and assure normality of the cycle under study, serum LH was measured daily starting from the mid follicular phase (days 7-10) and follicular growth was monitored by transvaginal ultrasound (TVU). Blood sampling and TVU were discontinued the following day after ovulation was detected. When the echo-image of the leading follicle was found to have disappeared or reduced at least $50 \%$, was taken as evidence that ovulation had occurred. A single pill containing mifepristone $200 \mathrm{mg}$ (HRA Pharma, Paris, France) or placebo was administered $48 \mathrm{~h}$ after the $\mathrm{LH}$ peak $(\mathrm{LH}+2)$ during the experimental and control cycles respectively and both types of pills were identical in appearance. Treatment was given at the clinic under supervision of a nurse in all cases. Endometrial samples were collected on $\mathrm{LH}+7$ under sterile conditions from the uterine fundus, using pipelle catheters (Laboratoire C.C.D., Paris, France). An additional blood sample was taken on the biopsy day to determine $\mathrm{P}_{4}$ serum level. The second part of the study involved another group of seven volunteers that met the same inclusion criteria as the group from the first part of our protocol. A straightforward follow up for a single menstrual cycle was done for these women that included daily serum LH measurements and TVU as described above. Two endometrial biopsies were obtained within that menstrual cycle on which no treatment was given. One biopsy was taken during the early secretory $(\mathrm{LH}+2)$ and another during the mid-secretory $(\mathrm{LH}+7)$ phase.

$\mathrm{LH}$ and $\mathrm{P}_{4}$ serum levels were determined as described before (Croxatto et al. 2004). For both parts of the study, each endometrial sample was divided into two and one piece was flash frozen in liquid nitrogen and stored at $-80^{\circ} \mathrm{C}$ for subsequent RNA isolation. The remainder piece was processed for histological assessment by an independent pathologist, under blind conditions, using the criteria described by Noyes et al. (1975).

\section{Isolation of RNA}

Total RNA was isolated from each tissue sample using Trizol reagent (Invitrogen) according to the instructions from the manufacturer. RNA concentration was determined by absorbance at $260 \mathrm{~nm}\left(\mathrm{~A}_{260}\right)$ and purity by calculating the $A_{260} / A_{280}$ ratio which varied between 1.8 and 2.1. The quality of the RNA was checked using the Agilent's Lab-on-a-Chip total RNA nano biosizing assay (Agilent Technologies, Inc., Palo Alto, CA, USA). The RNA integrity number was $>9.0$ for all samples analyzed.

\section{GeneChip hybridization}

Human Genome U133 plus 2.0 GeneChip oligonucleotide microarrays (Affymetrix, Sunnyvale, CA, USA) corresponding to 47000 transcripts and variants, including 38500 wellcharacterized human genes were used for gene expression analysis. Complementary RNA (cRNA) synthesis and array hybridization were performed according to the Affymetrix Expression Analysis Technical Manual. Briefly, $2 \mu \mathrm{g}$ of purified

Table 1 Characteristics of women participating in the study and parameters evaluated during the hormonal replacement cycle. All participating women had a BMI $\leq 30$ and hemoglobin levels $\geq 12 \mathrm{~g} / \mathrm{dl}$. Mean and range for each parameter is indicated in parenthesis.

\begin{tabular}{lcc}
\hline & Group MIF/placebo $(n=7)$ & Group untreated LH+ 2/LH+7 $(n=7)$ \\
\hline Age (years) & $36.1(32-39)$ & $35.4(30-40)$ \\
BMl & $25.2(23.4-30)$ & $25.6(20.8-29.7)$ \\
Hemoglobin $(\mathrm{g} / \mathrm{dl})$ & $14.6(13.7-15.9)$ & $13.5(12.4-14.7)$ \\
Number of live births $_{\text {Plasma progesterone }^{\mathrm{a}}(\mathrm{nmol} / \mathrm{l})}$ & $3.3(2-4)$ & $3.0(2-4)$ \\
\hline
\end{tabular}

${ }^{\mathrm{a}}$ On the day of biopsy. 
endometrial RNA was reverse transcribed using Whole Transcript cDNA Synthesis Kit (Affymetrix). After second strand synthesis biotin labeled cRNA from all endometrial samples was generated from the double strand template using T7 RNA polymerase (Affymetrix). In vitro transcription was performed to produce cRNA that was verified by Agilent's Lab-on-a-Chip total RNA nano biosizing assay. Twenty micrograms of biotinlabeled cRNA were hybridized to the microarrays chip for $16 \mathrm{~h}$ at $45^{\circ} \mathrm{C}$ in premixed hybridization solution containing labeled hybridization control prokaryotic genes (bioB, bioC, bioD and cre). Replicate spots for each control gene are present on the chip. Washing and fluorescent staining with streptavidinphycoerithrin were performed in the GeneChip Fluidics Station 450 and using the Affymetrix Staining Kit (Affymetrix). Microarrays were immediately scanned at a resolution of $6 \mu \mathrm{m}$ using a GeneChip Scanner 3000 (Affymetrix). Replicate hybridizations were performed for each RNA sample.

\section{Microarray data analysis}

Intensity values for the probes generated with the Affymetrix GeneChip Miroarray suite $v 1.4$ were exported to the Partek Genomics suite $\vee 6.3$ beta software (Partek Incorporated, St Louis, MO, USA) to determine gene expression differences and statistical analyses.

The sample size for this study was 14 subjects divided in two groups of seven. Since each women provided two endometrial samples (placebo/mifepristone or $\mathrm{LH}+2 / \mathrm{LH}+7$ ), a total of 28 samples were analyzed in duplicate. Data from all 56 arrays were normalized using Robust Multichip Average method (Irizarry et al. 2003) and used for further statistical analysis. To identify the differentially expressed genes between mifepristone and placebo groups; and $\mathrm{LH}+2$ and $\mathrm{LH}+7$ samples, a pairwise $t$-test was applied. To assess the results, the $P$ value $<0.001$ was used as a cutoff and a false discovery rate (FDR) of $1 \%$ was applied to the lists of genes. Finally, in addition to the appropriate correction for multiple testing, it was combined with a fold change of gene expression $\geq 2.0$, calculated as the average log-ratio between two groups to determine up- and down-regulated genes between groups.

Overlapping genes from differentially expressed transcripts among comparisons were determined and graphically represented using Venn Diagrams.

\section{Principal component analysis}

Principal component analysis (PCA) is a statistical technique for simplifying large amounts of data derived from microarray analysis (Joliffe \& Morgan 1992). The method reduces the dimensionality of multivariate data while preserving as much of the relevant information as possible. As a form of unsupervised learning, relies entirely on the input data itself without reference to the corresponding target data. Mathematically is the transformation of the data to a new coordinate system with three dimensions, such that the variables from the new set (the principal components) are linear functions of the original variables. This simplification determines the key variables that explain the differences between samples based on the expression profiles, allowing the summarization and further analysis of the microarray data. We applied the unbiased PCA algorithm using the Partek software to all samples using 54675 genes and ESTs represented on the microarray chip to look for expression patterns and underlying cluster structures.

\section{Hierarchical clustering}

Hierarchical clustering of endometrial samples was performed as another method of data structure visualization, using differentially expressed transcripts based on uncentered correlations with average linkage clustering. The resulting dendogram allows data structure visualization of endometrial samples according to total gene expression, revealing similar patterns of gene expression and relationships between the specimens and groups.

Over represented transcription factor binding sites detection in promoter regions of endometrial genes regulated by mifepristone

For a systematic search for potential over represented transcription factor binding sites (TFBS), the promoter region of our genes of interest defined as the region proximal to the transcription-start site of genes transcribed by RNA polymerase II, was analyzed. For that we used three bioinformatic approaches and platforms to increase the likelihood of our results: MotifScanner on software TOUCAN (Aerts et al. 2003), The Transcription Element Listening System (Cole et al. 2005) and Gene Annotation Tool to Help Explain Relationships (GATHER) (Chang \& Nevins 2006).

\section{Functional clustering}

The list of significantly regulated endometrial transcripts with mifepristone compared with placebo, obtained as described in the microarrays data analysis section, was used for functional clustering analyses in order to gain more insights about the biological process related to the regulated transcripts. The web-based tools Database for Annotation, Visualization and Integrated Discovery (DAVID) (Dennis et al. 2003) and GATHER (Chang \& Nevins 2006) were used as described before (Tapia et al. 2011). Both web-tool services obtain the biological meaning of submitted genes by retrieving their functional annotations from the Kyoto Encyclopedia of Genes and Genomes (Kanehisa et al. 2006), Biocarta pathways (http:// www.biocarta.com) and Gene Ontology (GO) (Ashburner et al. 2000) databases. No directionality is associated with the obtained relationships (i.e. the function should not be interpreted as being increased or decreased).

\section{Validation of microarray data by real-time RT-PCR}

Verification of microarrays data was performed by real-time RT-PCR analysis of selected genes using an ABI PRISM 7000 sequence detection system according to the manufacturer's instructions (Applied Biosystems). Briefly, first-strand cDNA was synthesized from total RNA of each endometrial sample in duplicate by reverse transcription using the SuperScript III reverse transcriptase (Invitrogen), according to the manufacturer's protocol. Pre-validated primers and TaqMan probes (Assays-on-demand, PE Applied Biosystems) were used for all 
transcripts in Table 2 to determine their respective transcript levels and GAPDH was used as a reference housekeeping gene. Quantitative analysis was based on the relative quantification of each gene of interest in the endometrial samples from of each group by using the $\Delta \Delta C T$ method (Livak \& Schmittgen 2001). Statistical significance was determined with the Wilcoxon two-sample paired signed rank test.

\section{Results}

\section{Anthropometric and functional parameters of subjects in placebo and mifepristone treated cycles}

A total of 28 endometrial biopsies were obtained. Sixteen samples were obtained from mifepristone- and placebo-treated cycles ( $n=7$ for each group) with two 'wash-out' cycles in between. Another 14 samples were obtained from spontaneous cycles on $\mathrm{LH}+2$ and $\mathrm{LH}+7$ days ( $n=7$ for each of the 2 collection days).

All $\mathrm{P}_{4}$ serum levels obtained on $\mathrm{LH}+7$ were within expected values for a spontaneous normal menstrual cycle $(>30 \mathrm{nmol} / \mathrm{l})$ with no statistically significant differences between the mifepristone- and placebotreated groups (Table 1) in agreement with previous reports (Swahn et al. 1990). No unscheduled bleeding or spotting was reported.

\section{PCA and hierarchical clustering}

PCA showed a clear segregation of samples according to their respective groups (Fig. 1A). As expected, endometrial gene expression profiles from the $\mathrm{LH}+7$ group clustered together with those from placebo group. Interestingly, biopsies taken on $\mathrm{LH}+2$ grouped along with the mifepristone-treated samples. Unsupervised hierarchical clustering analysis was applied for gene expression profiles from endometrial samples obtained from microarrays data. A dendogram was generated with the data from the endometrial samples from all groups in a tree-structured graph. The dendogram obtained displayed a striking segregation of samples into two major clustering branches, one corresponding to the $\mathrm{LH}+2$ and mifepristone groups and the other to the $\mathrm{LH}+7$ and placebo groups (Fig. 1B).

In the PCA and hierarchical clustering we found that the endometrial transcript profile during the window of

Table 2 Transcripts submitted to real-time RT-PCR confirmation.

\begin{tabular}{lll}
\hline UniGene ID & Gene name & Description \\
\hline Hs.404466 & CRISP3 & Cysteine-rich secretory protein 3 \\
Hs.204096 & SCGB1D2 & Secretoglobin, family 1D, member 2 \\
Hs.491232 & SLC39A14 & $\begin{array}{l}\text { Solute carrier family 39 (zinc transporter), } \\
\text { member 14 }\end{array}$ \\
Hs.70327 & CRIP1 & Cysteine-rich protein 1 (intestinal) \\
Hs.40499 & DKK1 & Dickkopf homolog 1 (Xenopus laevis) \\
Hs.183109 & MAOA & Monoamine oxidase A \\
Hs.278959 & GAL & Galanin prepropeptide \\
Hs.116651 & MPZL2 & Myelin protein zero-like 2 \\
\hline
\end{tabular}

implantation upon mifepristone administration is more similar to those obtained for early secretory endometrium during natural cycle. On the other hand, the endometrial transcript profiles from endometrial samples obtained in mid secretory phase upon placebo where indistinguishable from those obtained during the window of implantation during a non-treated spontaneous cycles and clustered separately from the other two groups.

\section{Transcripts with differential expression in the endometrium after post ovulatory administration of mifepristone}

We identified a total of 2119 transcripts corresponding to known genes whose expression altered significantly in the uterus at the time of implantation in response to mifepristone which represents a $\sim 4.7 \%$ of the total number of transcripts represented in the microarrays chip. In total, 766 and 1353 transcripts were up- and down-regulated respectively in receptive endometrium upon administration of mifepristone $200 \mathrm{mg}$ on day $\mathrm{LH}+2$ of the menstrual cycle compared with the time matched placebo group. In Tables 3 and 4 are shown the top 100 endometrial genes whose transcript levels increased and decreased respectively, upon mifepristone administration.

When the endometrial samples obtained on day $\mathrm{LH}+2$ were compared with those obtained on day $\mathrm{LH}+7$ during the same spontaneous cycle, 1915 transcripts were differentially expressed $(\sim 3.5 \%$ of transcripts assayed in the microarrays assay) with 893 and 1022 transcripts up- and down-regulated respectively. Seven hundred and seventy seven transcripts out of the total of differentially expressed genes from pre-receptive $(\mathrm{LH}+2)$ to receptive endometrium $(\mathrm{LH}+7)$ were common to those obtained with the administration of mifepristone compared with placebo (Fig. 2). Interestingly, 752 of them displayed opposite regulation directionalities whereas 25 changed in the same direction as mifepristone. It should be pointed out that such concordance of differentially expressed transcripts with opposed regulation is likely to be the main driver for the cluster structures found with PCA and hierarchical clustering.

Integration and cross-validation of human endometrial transcriptome during the window of implantation reported by different groups could increase the confidence in the detection of regulated transcripts for many more genes than is tractable with classical validation (Kemmeren et al. 2002, Rhodes et al. 2002). The available data sets comparing endometrial gene expression profiles during spontaneous cycles from the proliferative vs mid secretory phase (Kao et al. 2002, Borthwick et al. 2003), from early secretory vs mid secretory phase (Carson et al. 2002, Riesewijk et al. 2003, Mirkin et al. 2005, Talbi et al. 2006) and with a single dose of mifepristone $200 \mathrm{mg}$ on $\mathrm{LH}+8$ after 6 and 


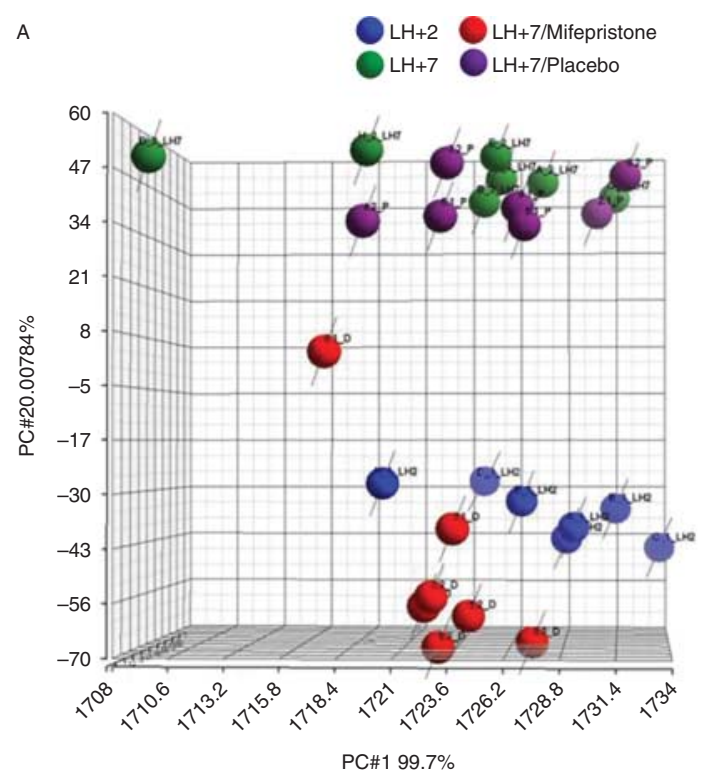

B

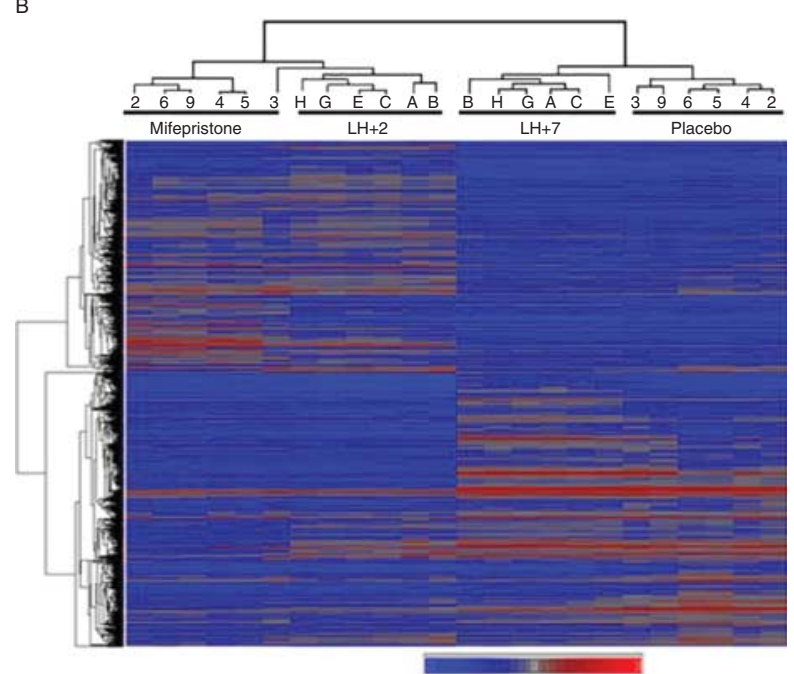

Figure 1 Unsupervised analyses of microarrays data. Principal component analysis (PCA) plot (A) and Hierarchical clustering (B) of gene expression profiles from endometrial samples. PCA included 28 endometrial samples whose gene expression profiles were obtained by microarray analysis. Blue dots $=$ samples obtained on $\mathrm{LH}+2$, green dots = samples obtained on $\mathrm{LH}+7$, purple dots= samples obtained in $\mathrm{LH}+7$ with administration of placebo and red dots $=$ samples obtained on $\mathrm{LH}+7$ with administration of mifepristone. Endometrial samples from the reference group on $\mathrm{LH}+2$ and $\mathrm{LH}+7$ (blue and green dots) were obtained during the same spontaneous cycle of each women. The profiles from the mifepristone group (red dots) cluster together with those for the $\mathrm{LH}+2$ reference group whereas the samples from the placebo group cluster along with the $\mathrm{LH}+7$ reference group. Hierarchical clustering analysis represented in a tree-like dendogram revealing the similarities on gene expression profiles of 28 endometrial samples. Each row represents a transcript and each column the gene expression profile of a particular endometrial sample. A clear segregation of samples into two major clustering branches, one with samples from mifepristone and $\mathrm{LH}+2$ groups and the other with samples from placebo and $\mathrm{LH}+7$ groups, is shown. Most gene expression profiles self-cluster together with others from their respective group.
$24 \mathrm{~h}$ of administration vs placebo (Catalano et al. 2007) were contrasted with our data sets from microarrays analysis. We found 14 transcripts regulated by mifepristone (13 down- and 1 up-regulated) that also have been reported in the opposite direction during the window of implantation in at least four different studies and in our reference group (Table 5). The transcript CLDN4 was coincident with five reports but not significantly regulated in our reference group. Interestingly, we found only two coincident transcripts (MMP7 and CXCL12) in the study of Catalano et al. (2007) displaying the same regulatory direction with our study group and that have also been reported for the acquisition of receptivity; however the described regulatory behavior during spontaneous cycles is not the opposite in all of them.

\section{Identification of overrepresented consensus sequences for TFBS sites of transcripts regulated by mifepristone}

To identify potential common regulatory pathways in endometrial genes regulated by mifepristone, we performed an analysis for detection of over-represented promoter sequences using three bioinformatics tools. First, the potential TFBS were detected and then those statistically over-represented in our set of regulated endometrial genes were determined. The results are listed in Table 6 for up- and down-regulated transcripts respectively. Interestingly, DNA binding sites for seven transcription factors were identified as overrepresented in both increased and decreased transcripts whereas other 16 and 24 overrepresented TFBS where unique for up- and down-regulated genes respectively.

\section{Functional clustering of endometrial transcripts regulated by mifepristone}

In order to gain further understanding of the potential functional roles of dysregulated endometrial transcripts from group A, we obtained the functional annotations from each gene and determined the enriched processes associated with them from two different web-based tools. Within the up-regulated transcripts, the functional classifications related to cell adhesion and proliferation, were found to be statistically over-represented in both web-based tools used (Tables 7 and 8). The downregulated transcript list was not enriched with transcripts related to coincident functions in the two analysis performed for functional annotation clusters.

\section{Real-time RT-PCR confirmation}

In order to confirm differences in transcript levels found with the microarrays, five genes (CRISP3, GAL, MAOA, SLC39A14 and DKK1) whose mRNA steady-state level increased in the comparison $\mathrm{LH}+2$ vs $\mathrm{LH}+7$ and showed an opposite regulation upon mifepristone 


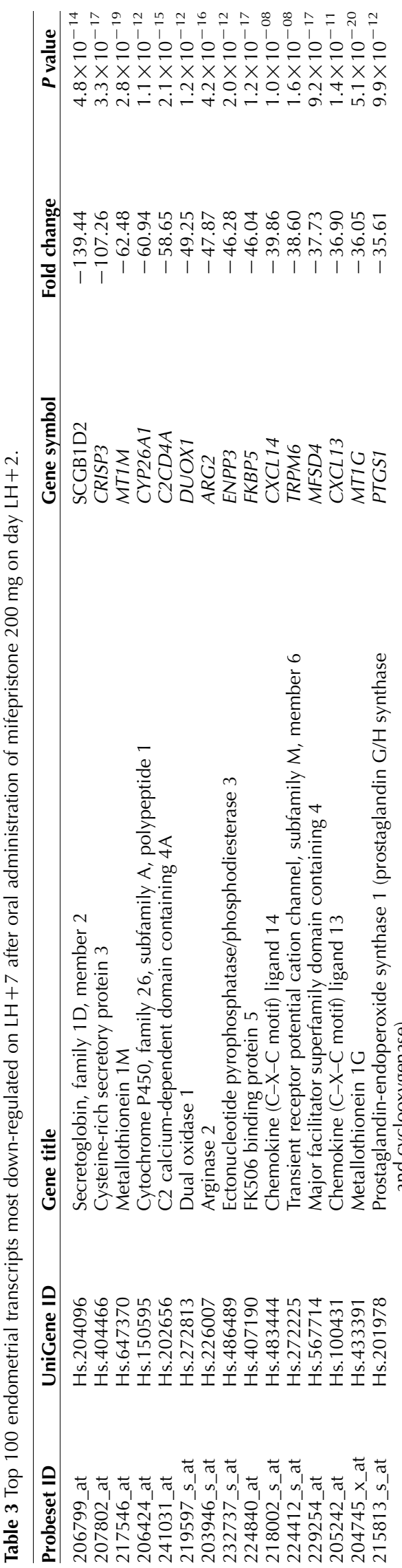

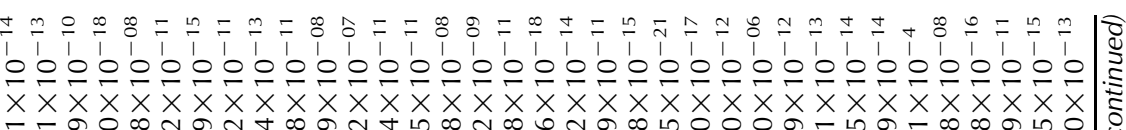
न

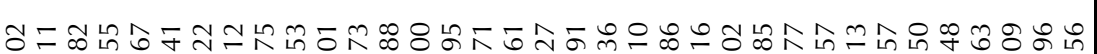
m்

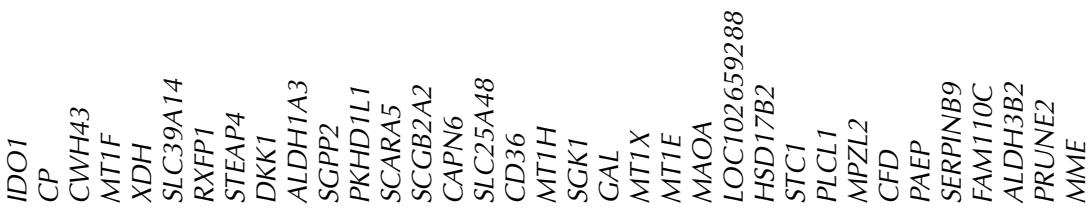

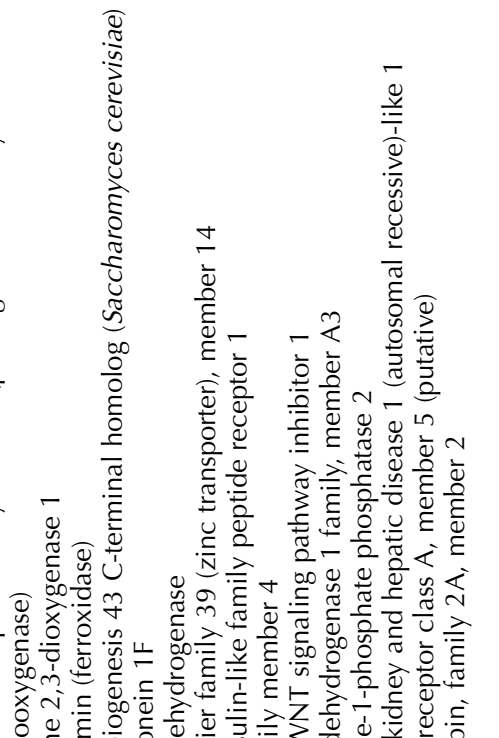

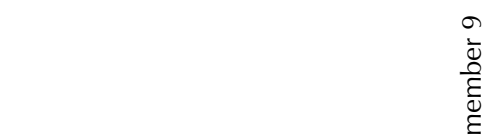

है

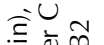

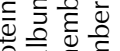

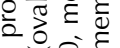
$\frac{0}{0}=$

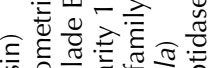
政

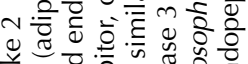
हो

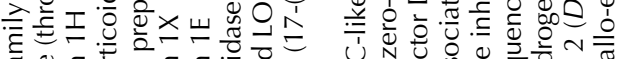

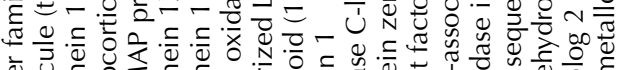

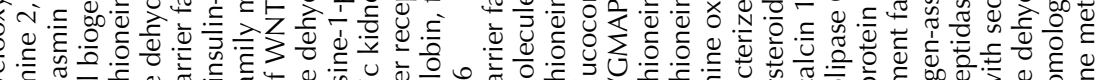

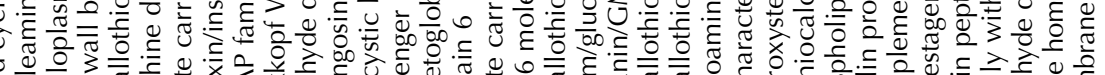
Min

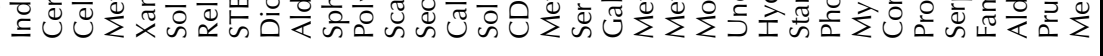




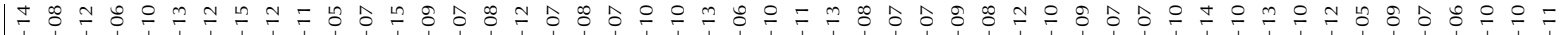

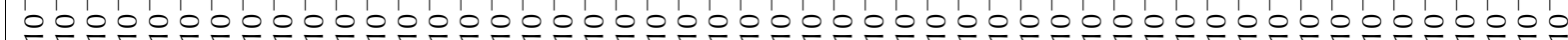

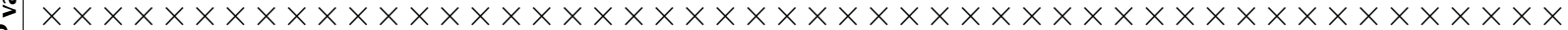
ம்

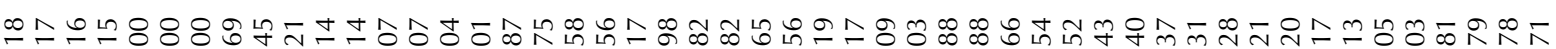

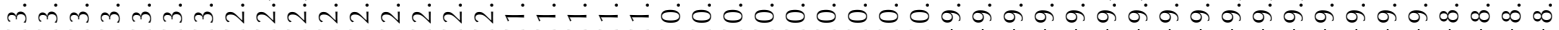
흔

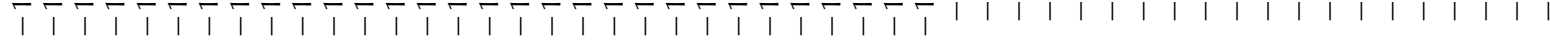

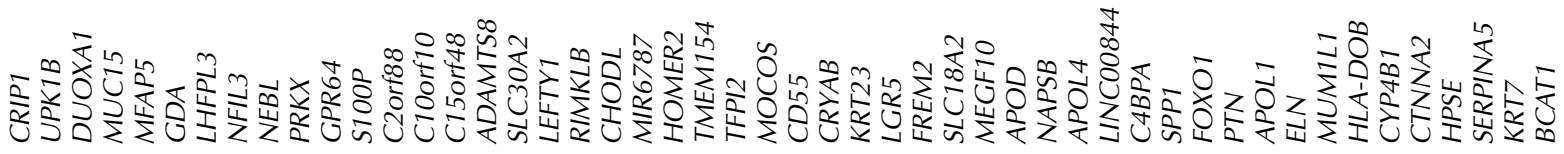

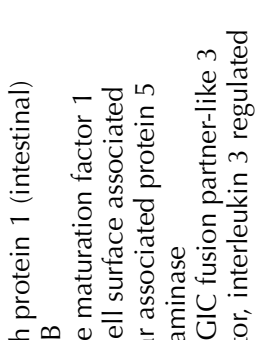

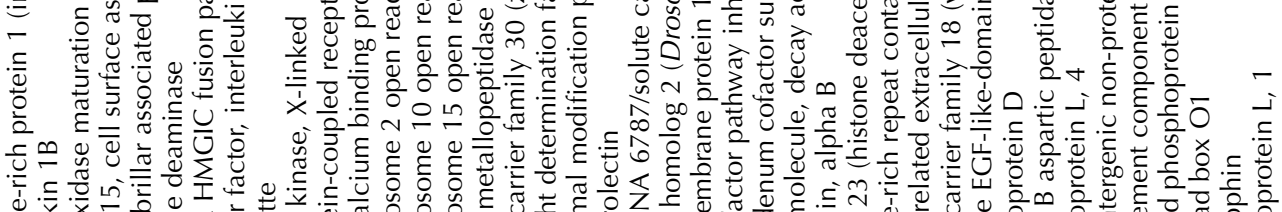

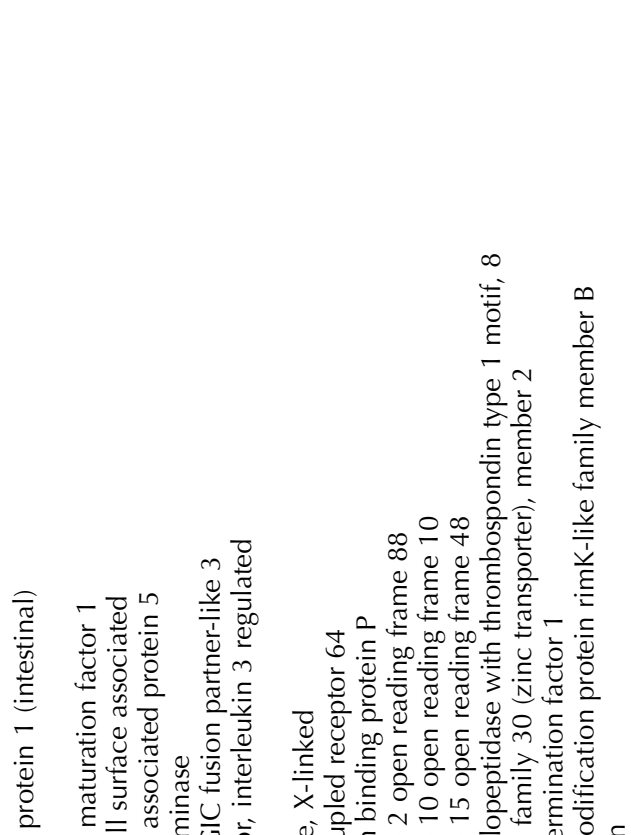

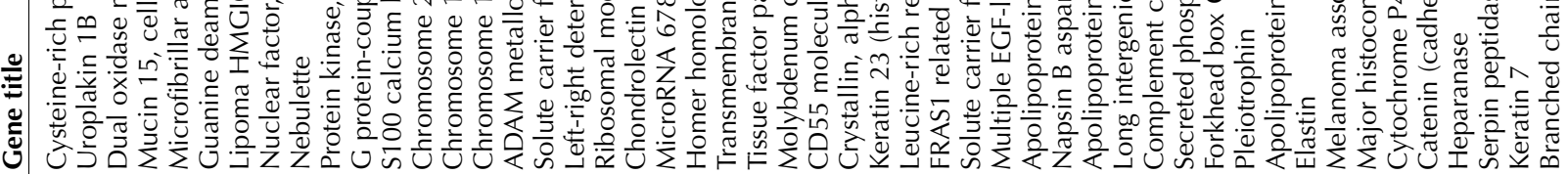

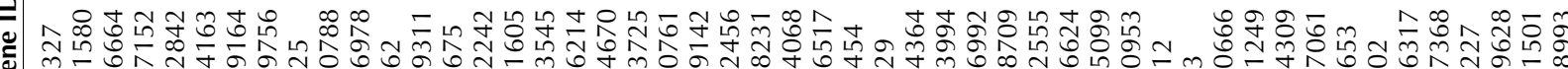

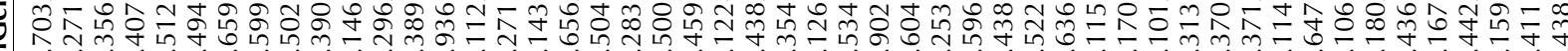

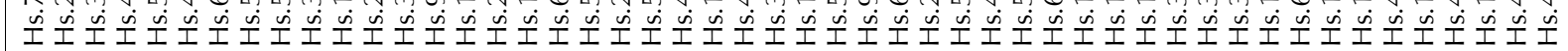

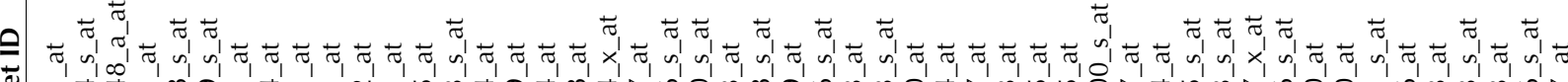

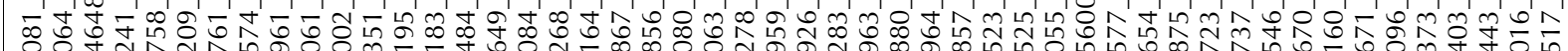

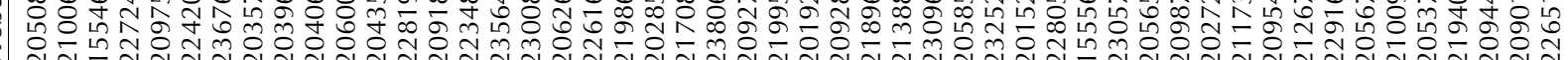




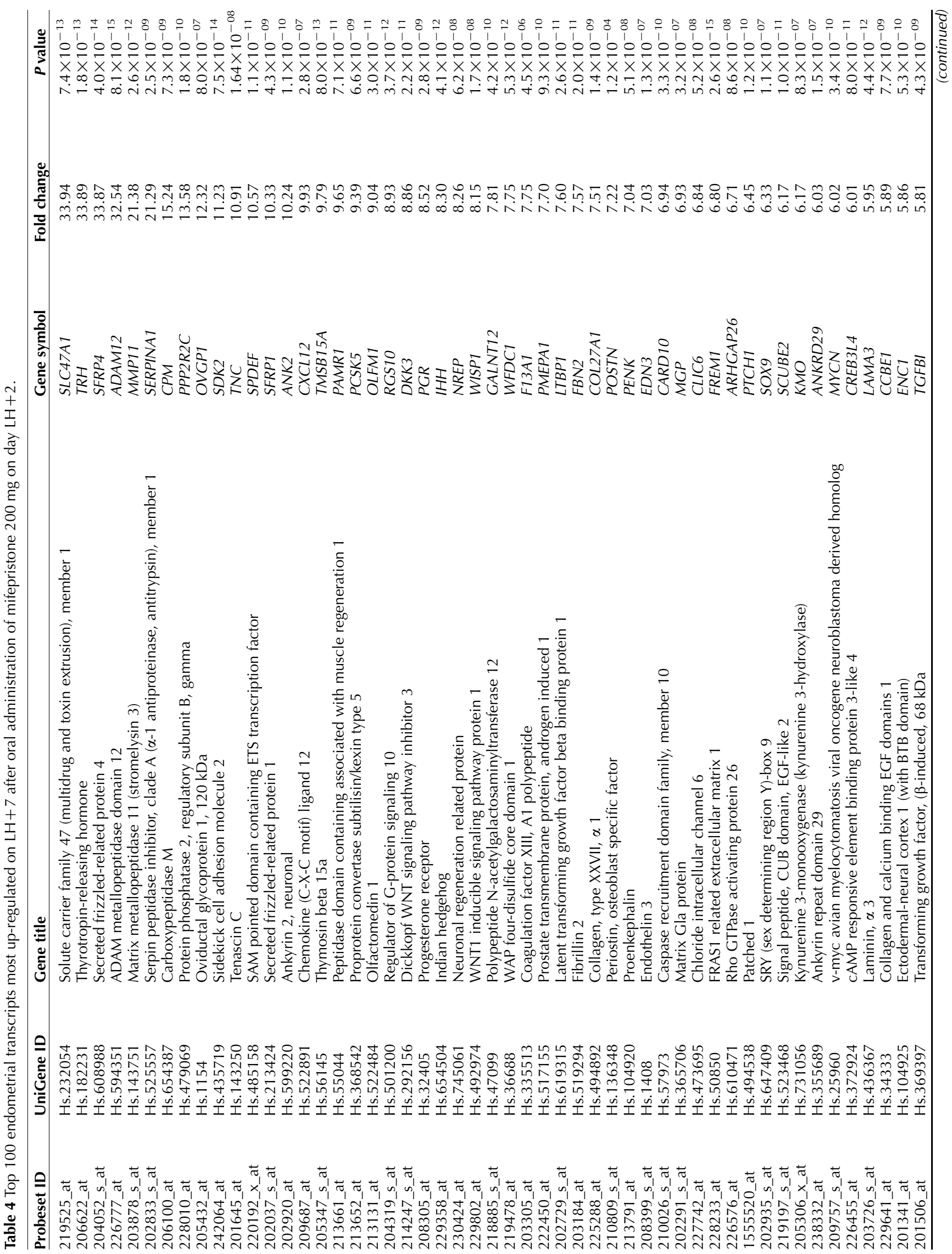




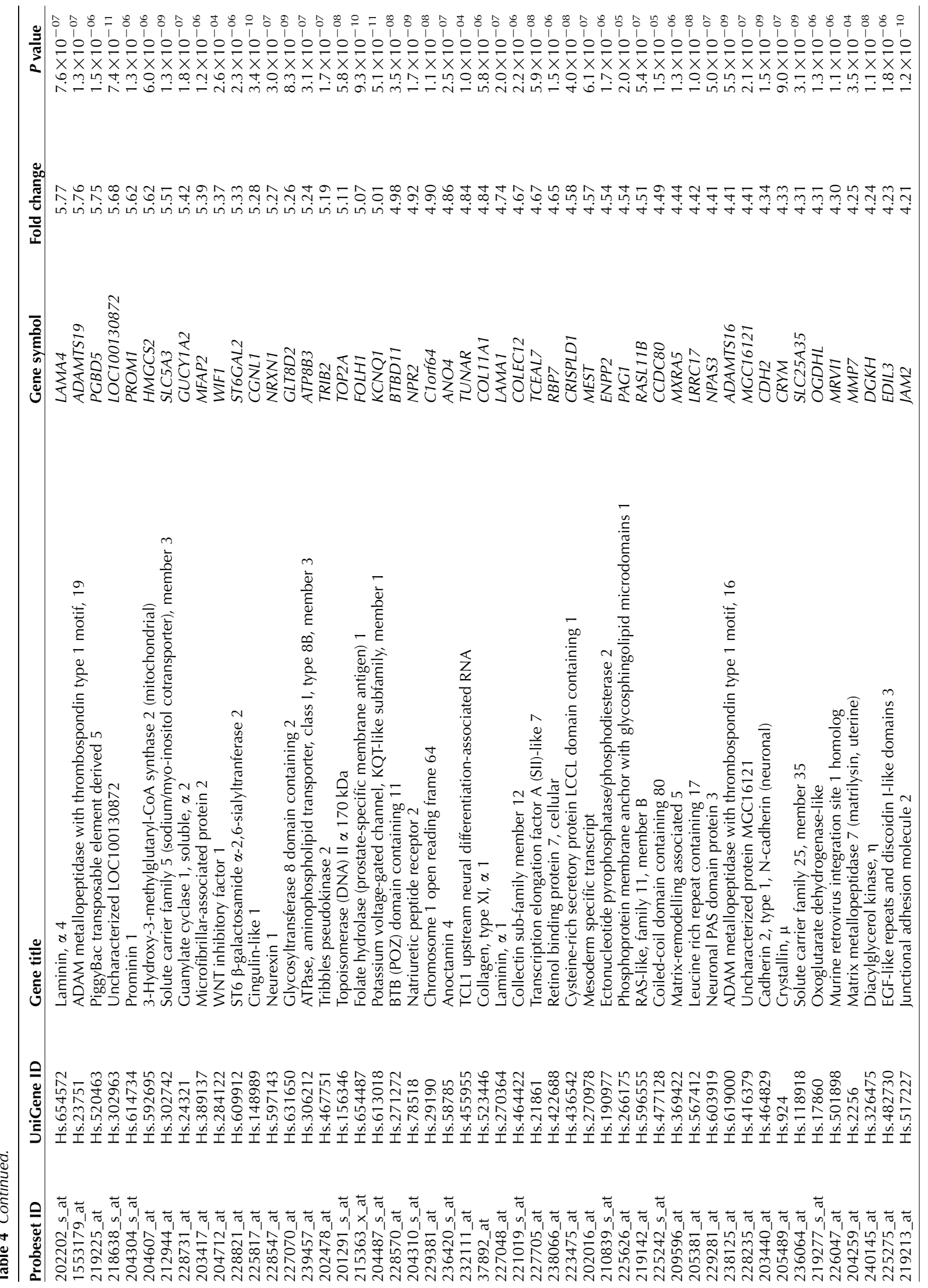




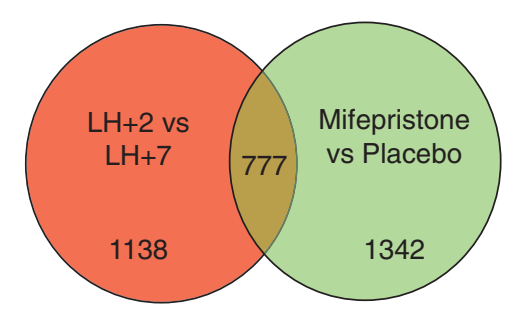

Figure 2 Venn diagram from differentially expressed transcripts in the experimental and reference groups. The green circle indicates the number of transcripts significantly regulated in the endometrium of women on day $\mathrm{LH}+7$ with oral postovulatory administration of mifepristone (mifepristone vs placebo). The red circle indicates those significantly regulated during the acquisition of endometrial receptivity $(\mathrm{LH}+2$ vs $\mathrm{LH}+7)$.

administration, were submitted to real-time RT-qPCR analysis. Additionally, transcript level for other three genes (SGB1D2, EVA1 and CRIP1) that were shown to decrease in the mifepristone-treated group but did not show significant variation in the comparison $\mathrm{LH}+2 \mathrm{vs}$ $\mathrm{LH}+7$, was analyzed by RT-qPCR. The mRNA levels for the eight genes analyzed were reduced in the mifepristone treated group compared with the placebo group in agreement with the microarray data (Fig. 3). The transcript level of CRISP3, GAL, MAOA, SLC39A14 and $D K K 1$ increased in the $\mathrm{LH}+7$ group compared with the $\mathrm{LH}+2$ group, however the level for SCGB1D2, EVA1 y CRIP1 was not statistically significant amongst these groups (Fig. 3); in line with the microarrays results.

\section{Discussion}

We determined the endometrial gene expression profile in human endometrium under four different conditions analyzing 54675 transcripts that cover most of the known human genes reported. The endometrial samples were characterized at the molecular level organized in the unsupervised analyses PCA and hierarchical clustering. Each sample seems to have an expression profile that self-cluster with its own group. The gene expression profile of endometrial samples on $\mathrm{LH}+7$ with mifepristone is similar to the one obtained with samples obtained in $\mathrm{LH}+2$, and the profile of samples obtained in $\mathrm{LH}+7$ with no treatment or with placebo are similar amongst them but different to the other two groups. For microarrays data validation, we confirmed by qPCR the transcript level of eight genes that were differentially expressed in the microarrays analysis during the window of implantation after mifepristone administration on $\mathrm{LH}+2$. Although a relatively small number of transcripts were confirmed, considering that in other studies using the same microarrays platform we used have given a good correlation for gene expression confirmation, we consider such validation confers a reasonable validity to the groups of regulated transcripts.
The 2119 transcripts whose abundance was found altered 5 days after mifepristone administration on $\mathrm{LH}+2$ in comparison with the placebo group is the most novel finding of this work. Since the most remarkable pharmacological property of mifepristone is to block $\mathrm{P}_{4}$ action, we presume these genes are regulated either directly or indirectly by $\mathrm{P}_{4}$. Such presumption is in line with the finding that almost all transcripts that changed its level in the transition from $\mathrm{LH}+2$ to $\mathrm{LH}+7$ changed in the opposite direction of the mifepristone group compared with placebo. However such fact did not occur for 25 transcripts whose expression level changed significantly but in the same direction. This transcript regulation could be explained by an agonistic effect on these $\mathrm{P}_{4}$ regulated transcripts. The agonistic effect of mifepristone has been described before in the endometrium from postmenopausal women with the induction of secretory changes after inducing proliferation with exogenous estradiol (Gravanis et al. 1985). Such progestogenic effect of mifepristone has been documented in vitro in endometrial cell lines as well. In HeLa cells co-transfected with reporter genes and an expression vector with the PGR, an agonistic effect of mifepristone was described on gene expression (Meyer et al. 1990, Tung et al. 1993, Jackson et al. 1997) which depends on the isoform of the PGR mifepristone binds to and the cell context (Meyer et al. 1990). The gene expression profile analysis of Ishikawa cells in presence of $\mathrm{P}_{4}$ or mifepristone showed that mifepristone induces a transcriptional behavior with both agonistic and antagonistic activity of $\mathrm{P}_{4}$ (Tamm-Rosenstein et al. 2013). Regardless of the unexpected behavior of these 25 transcripts, it is unlikely they are involved in the anti-implantation effect driven by mifepristone.

The endometrium is composed of an heterogeneous population of cells including mesodermal-derived glandular and luminal epithelial cells that are supported by a basement membrane and uterine fibroblasts, vascular smooth cells, endothelial cells and lymphoid cells in the connective stroma. These cells have been described to respond differentially to the ovarian steroidal hormones. The endometrial samples analyzed in the present study, are processed combining all the cell types composing the tissue, hence it is difficult to put the regulated transcripts in context of a complex tissue. In this sense it is required further identification of the endometrial cell types expressing the genes of interest by techniques such as immunohistochemistry or in situ hybridization. An alternative approach has been to analyze separately the endometrial compartments during the window of implantation by laser capture microdissection (Torres et al. 2002, Evans et al. 2012, Evans et al. 2014). These studies may contribute to the understanding on the regulation exerted by progesterone on specific endometrial compartments.

In the present study, we used two independent clustering strategies to analyze the microarrays data 


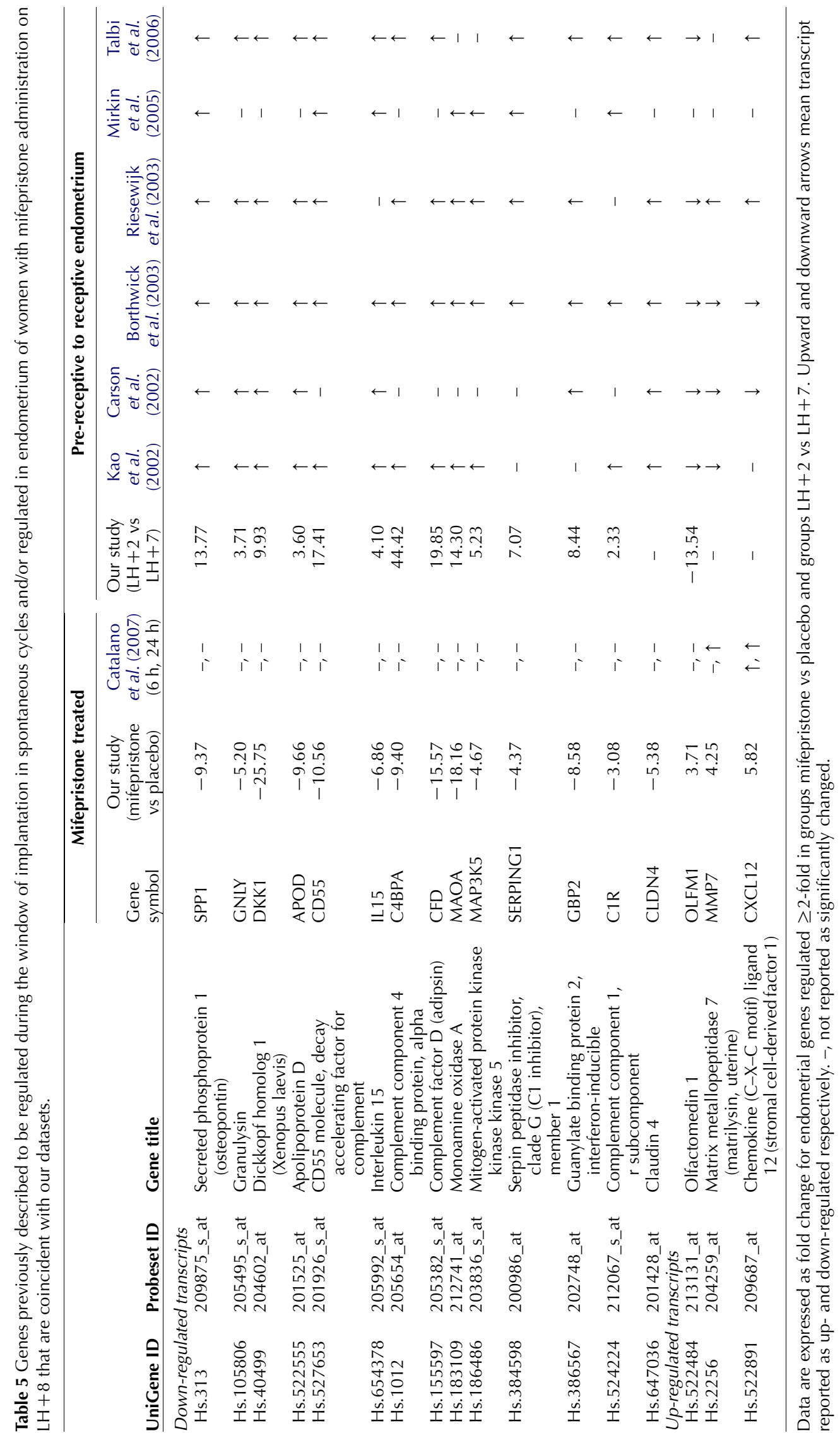


Table 6 Transcription factor binding sites (TFBS) over represented in up- and down- regulated genes in the endometrium from the mifepristone group.

\begin{tabular}{|c|c|c|c|c|c|c|}
\hline \multirow[b]{2}{*}{ Tool for TFBS analysis } & \multicolumn{3}{|c|}{ Up-regulated genes } & \multicolumn{3}{|c|}{ Down-regulated genes } \\
\hline & Matrix ID & Transcription factor & $P$ value & Matrix ID & Transcription factor & $P$ value \\
\hline \multirow[t]{7}{*}{ MotifScanner } & PAX4_04 & Paired box 4 & 0.0007 & E47_02 & Transcription factor E47 & $<0.0001$ \\
\hline & & & & SREB̄P1_01 & $\begin{array}{l}\text { Sterol regulatory binding } \\
\text { protein } 1\end{array}$ & $<0.0001$ \\
\hline & & & & PAX4_04 & Paired box 4 & $<0.0001$ \\
\hline & & & & AREB6_03 & $\begin{array}{l}\text { ARE (Atp1a1 regulatory } \\
\text { element) B6 }\end{array}$ & 0.0005 \\
\hline & & & & TAL1BETAITF2_01 & Tal-1 $\beta /$ ITF-2 heterodimer & 0.0015 \\
\hline & & & & TAL1ALPHAE47_01 & Tal-1 $\alpha /$ E47 heterodimer & 0.0017 \\
\hline & & & & MEF2_02 - 04 & $\begin{array}{l}\text { Myocyte-specific enhancer } \\
\text { factor } 2 \mathrm{~A}\end{array}$ & 0.0024 \\
\hline \multirow{18}{*}{$\begin{array}{l}\text { Transcription Element } \\
\text { Listening System }\end{array}$} & USF_02 & Upstream stimulating factor & 0.0004 & SP1_Q6 & Stimulating protein 1 & $<0.0001$ \\
\hline & CAP_01 & $\begin{array}{l}\text { Cap signal for transcription } \\
\text { initiation }\end{array}$ & 0.0005 & SP1_01 & Stimulating protein 1 & 0.0001 \\
\hline & SP1_Q6 & Stimulating protein 1 & 0.0028 & ELK1_02 & Elk-1 & 0.0006 \\
\hline & NRF2_01 & Nuclear respiratory factor 2 & 0.0039 & NRF2_01 & Nuclear respiratory factor 2 & 0.0008 \\
\hline & E47_02 & Transcription factor E47 & 0.0069 & MZF1_01 & $\begin{array}{l}\text { Myeloid zinc finger protein } \\
\text { MZF1 }\end{array}$ & 0.0014 \\
\hline & ELK1_02 & Elk-1 & 0.0073 & GC_01 & GC box elements & 0.0015 \\
\hline & MZF1_02 & $\begin{array}{l}\text { Myeloid zinc finger protein } \\
\text { MZF1 }\end{array}$ & 0.0119 & CETS1P54_02 & c-Ets-1(p54) & 0.0116 \\
\hline & YY1_01 & Yin and Yang 1 & 0.0126 & VMYB_01 & v-Myb, viral myb & 0.0216 \\
\hline & AP2_Q6 & Activator protein 2 & 0.0151 & CETS1P54_01 & c-Ets-1(p54) & 0.0224 \\
\hline & GC_01 & GC box elements & 0.0176 & CDXA_01 & $\begin{array}{l}\text { Caudal-type homeodomain } \\
\text { protein }\end{array}$ & 0.0246 \\
\hline & MYCMAX_02 & c-Myc/Max heterodimer & 0.0204 & VMYB_02 & v-Myb, viral myb & 0.0258 \\
\hline & PBX1_01 & Homeo domain factor $\mathrm{Pbx}-1$ & 0.0275 & AP4_Q6 & Activator protein 4 & 0.0260 \\
\hline & CAAT_C & Cellular and viral CCAAT box & 0.0306 & CHŌP_01 & $\begin{array}{l}\text { Heterodimers of CHOP } \\
\text { and C/EBPalpha }\end{array}$ & 0.0295 \\
\hline & MZF1_01 & $\begin{array}{l}\text { Myeloid zinc finger protein } \\
\text { MZF1 }\end{array}$ & 0.0325 & EGR3_01 & $\begin{array}{l}\text { Early growth response gene } \\
3 \text { product }\end{array}$ & 0.0358 \\
\hline & ER_Q6 & Estrogen receptor- $\alpha$ & 0.0402 & OCT1_03 & Octamer-binding factor 1 & 0.0365 \\
\hline & GATA2_01 & GATA-binding factor 2 & 0.0484 & OCT1_01 & Octamer-binding factor 1 & 0.0396 \\
\hline & & & & MEF2_01 & Myogenic enhancer factor 2 & 0.0400 \\
\hline & & & & HNF4_01 & $\begin{array}{l}\text { Hepatic nuclear factor } 4, \\
\text { DR1 sites }\end{array}$ & 0.0495 \\
\hline \multirow{7}{*}{$\begin{array}{l}\text { Gene Annotation Tool } \\
\text { to Help Explain } \\
\text { Relationships }\end{array}$} & NRF2_01 & Nuclear respiratory factor 2 & $<0.0001$ & NFKAPPAB_01 & $N F \kappa B$ & $<0.0001$ \\
\hline & GABP_B & GA repeat binding protein & $<0.0001$ & NFKB_Q6 & $N F \kappa B$ & 0.0001 \\
\hline & KROX_Q6 & Egr-1,2,3,4 & 0.0002 & NRF2_01 & nuclear respiratory factor 2 & 0.0001 \\
\hline & CETS168_Q6 & c-Ets & 0.0003 & YY1_02 & Yin and Yang 1 & 0.0002 \\
\hline & E2F1_Q3_01 & E2F Transcription Factor 1 & 0.0008 & MAZR_01 & MAZ related factor & 0.0003 \\
\hline & DEC_Q1 & Dec transcription factor & 0.001 & & & \\
\hline & NFY_Q6_01 & Nuclear factor $Y$ & 0.001 & & & \\
\hline
\end{tabular}

Transcription factors predicted by more than one analysis tool appear in bolded style.

from the endometrial tissues and to analyze how samples cluster together based on similarities in their transcript profiles. Both clustering methods using different algorithms generated equivalent patterns of segregation of samples suggesting that the endometrial samples from day $\mathrm{LH}+7$ obtained from women with mifepristone have a gene expression profile that does not progress from $\mathrm{LH}+2$, highlighting the $\mathrm{P}_{4}$ signaling restrain.

When mifepristone is administered immediately after ovulation, it prevents the PGR and estrogen receptor down-regulation induced by $\mathrm{P}_{4}$ which occurs during the luteal phase (Maentausta et al. 1993) suggesting a sustained endometrial stimulation by estrogen upon mifepristone administration. $\mathrm{P}_{4}$ signaling inhibits the estrogen signaling pathways in the uterus (Hsueh et al. 1975) and this inhibitory relationship involving both hormone pathways orchestrate the regulatory mechanisms required for endometrial receptivity and embryo implantation. Amongst the regulated transcripts in the mid-secretory endometrium from women with mifepristone administration we found several genes involved in the $\mathrm{P}_{4}$ signaling axis including modulators and effectors with down regulation of NCOA2 (SRC-2, (Mukherjee et al. 2006, Jeong et al. 2007)), IHH (Matsumoto et al. 2002, Takamoto et al. 2002), ERRFI1 (MIG6, (Kim et al. 2010)) PTCH1 (Lee et al. 2006) and $D K K 1$ (Tulac et al. 2006); and up-regulation of ESR1 (Curtis et al. 1999), PRA (Conneely \& Lydon 2000), FKBP5 (Tranguch et al. 2005), FOXO1A (Kim et al. 2005), KLF9 (Simmen et al. 2004) and PTGS1 (Wang et al. 2004).

With regard to the identification of key genes responsible for endometrial receptivity, Catalano et al. (2003) analyzed the endometrial gene expression profile 
Table 7 Functional annotation clusters for up- and down-regulated transcripts in the endometrium from the mifepristone group, obtained through Gene Annotation Tool to Help Explain Relationships (GATHER) webtool.

\begin{tabular}{|c|c|c|c|}
\hline Database & Functional annotation & Number of genes & $P$ value \\
\hline \multicolumn{4}{|c|}{ Up-regulated transcripts } \\
\hline GO:0007067 [8] & Mitosis & 23 & $<0.0001$ \\
\hline GO:0000087 [7] & M phase of mitotic cell cycle & 23 & $<0.0001$ \\
\hline GO:0000278 [6] & Mitotic cell cycle & 27 & $<0.0001$ \\
\hline GO:0007155 [4] & Cell adhesion & 47 & $<0.0001$ \\
\hline GO:0000280 [7] & Nuclear division & 23 & $<0.0001$ \\
\hline GO:0000279 [6] & M phase & 23 & $<0.0001$ \\
\hline GO:0007275 [2] & Development & 91 & $<0.0001$ \\
\hline GO:0009653 [3] & Morphogenesis & 62 & $<0.0001$ \\
\hline GO:0007049 [5] & Cell cycle & 43 & $<0.0001$ \\
\hline GO:0008283 [4] & Cell proliferation & 56 & $<0.0001$ \\
\hline GO:0000910 [5] & Cytokinesis & 14 & $<0.0001$ \\
\hline GO:0016055 [6] & WNT receptor signaling pathway & 12 & $<0.0001$ \\
\hline \multicolumn{4}{|c|}{ Down-regulated transcripts } \\
\hline GO:0006955 [4] & Immune response & 66 & $<0.0001$ \\
\hline GO:0009607 [4] & Response to biotic stimulus & 76 & 0.0001 \\
\hline GO:0007186 [6] & G-protein coupled Receptor signaling pathway & 22 & 0.0001 \\
\hline GO:0006952 [5] & Defense response & 68 & 0.0002 \\
\hline
\end{tabular}

Enriched functional annotations found in GATHER (Table 7) and Database for Annotation, Visualization and Integrated Discovery (Table 8) appear in bold.

under mifepristone stimulation using the endometrial tissue explant during the receptive phase. Explants were analyzed with a DNA microarray that investigated 1000 genes involved in cell adhesion, signaling, apoptosis, cell cycle regulation, extracellular matrix remodeling and angiogenesis.

When mifepristone is administered during the midluteal phase of the menstrual cycle, it induces uterine bleeding due to endometrial breakdown within $72 \mathrm{~h}$ of administration in a similar way as $\mathrm{P}_{4}$ withdrawal induces menstruation (Swahn et al. 1988). Catalano identified genes regulated by $\mathrm{P}_{4}$ in human endometrium in vivo with the administration of $200 \mathrm{mg}$ of mifepristone during mid-secretory phase. Under these circumstances, $\mathrm{P}_{4}$ had already started to exert its effects in the endometrium and mifepristone induces menses within $48 \mathrm{~h}$. Hence, the block of $\mathrm{P}_{4}$ action during mid-secretory phase not only renders the endometrium unreceptive but also induces processes involved in menstruation generating a confounding effect that difficult the identification of transcripts involved in endometrial receptivity. When mifepristone is administered immediately after ovulation, the length of the menstrual cycle and plasmatic levels of estradiol and $\mathrm{P}_{4}$ are not affected (Swahn et al. 1990), however induces a dramatic effect on endometrial development (Dockery et al. 1997, Danielsson et al. 2003). For these reasons we chose for the present study, administering mifepristone on the

Table 8 Functional annotation clusters for up- and down-regulated transcripts in the endometrium from the mifepristone group, obtained through Database for Annotation, Visualization and Integrated Discovery (DAVID) webtool.

\begin{tabular}{|c|c|c|c|}
\hline Database & Functional annotation & Number of genes & $P$ value \\
\hline \multicolumn{4}{|c|}{ Up-regulated transcripts } \\
\hline GOTERM BP FAT & Cell adhesion & 59 & $<0.0001$ \\
\hline GOTERM_BP_FAT & Biological adhesion & 59 & $<0.0001$ \\
\hline GOTERM_BP_FAT & Mitosis & 30 & $<0.0001$ \\
\hline GOTERM BP FAT & Nuclear division & 30 & $<0.0001$ \\
\hline GOTERM_BP_FAT & M phase of mitotic cell cycle & 30 & $<0.0001$ \\
\hline GOTERM BP FAT & Organelle fission & 30 & $<0.0001$ \\
\hline GOTERM_BP_FAT & Mitotic cell cycle & 38 & $<0.0001$ \\
\hline GOTERM_BP_FAT & Cell cycle phase & 39 & $<0.0001$ \\
\hline GOTERM_BP_FAT & M phase & 34 & $<0.0001$ \\
\hline GOTERM_BP_FAT & Cell cycle process & 46 & $<0.0001$ \\
\hline GOTERM BP FAT & Cell cycle & 55 & $<0.0001$ \\
\hline GOTERM_BP_FAT & Cell division & 30 & $<0.0001$ \\
\hline \multicolumn{4}{|c|}{ Down-regulated transcripts } \\
\hline GOTERM BP FAT & Anti-apoptosis & 28 & $<0.0001$ \\
\hline GOTERM_BP_FAT & Negative regulation of programmed cell death & 39 & $<0.0001$ \\
\hline GOTERM BP FAT & Negative regulation of cell death & 39 & $<0.0001$ \\
\hline GOTERM_BP_FAT & Negative regulation of apoptosis & 38 & $<0.0001$ \\
\hline GOTERM_BP_FAT & Response to organic substance & 61 & $<0.0001$ \\
\hline GOTERM_BP_FAT & Regulation of cell proliferation & 65 & $<0.0001$ \\
\hline GOTERM_BP_FAT & Response to endogenous stimulus & 39 & $<0.0001$ \\
\hline
\end{tabular}

Enriched functional annotations found in Gene Annotation Tool to Help Explain Relationships (Table 7) and DAVID (Table 8) appear in bold. 

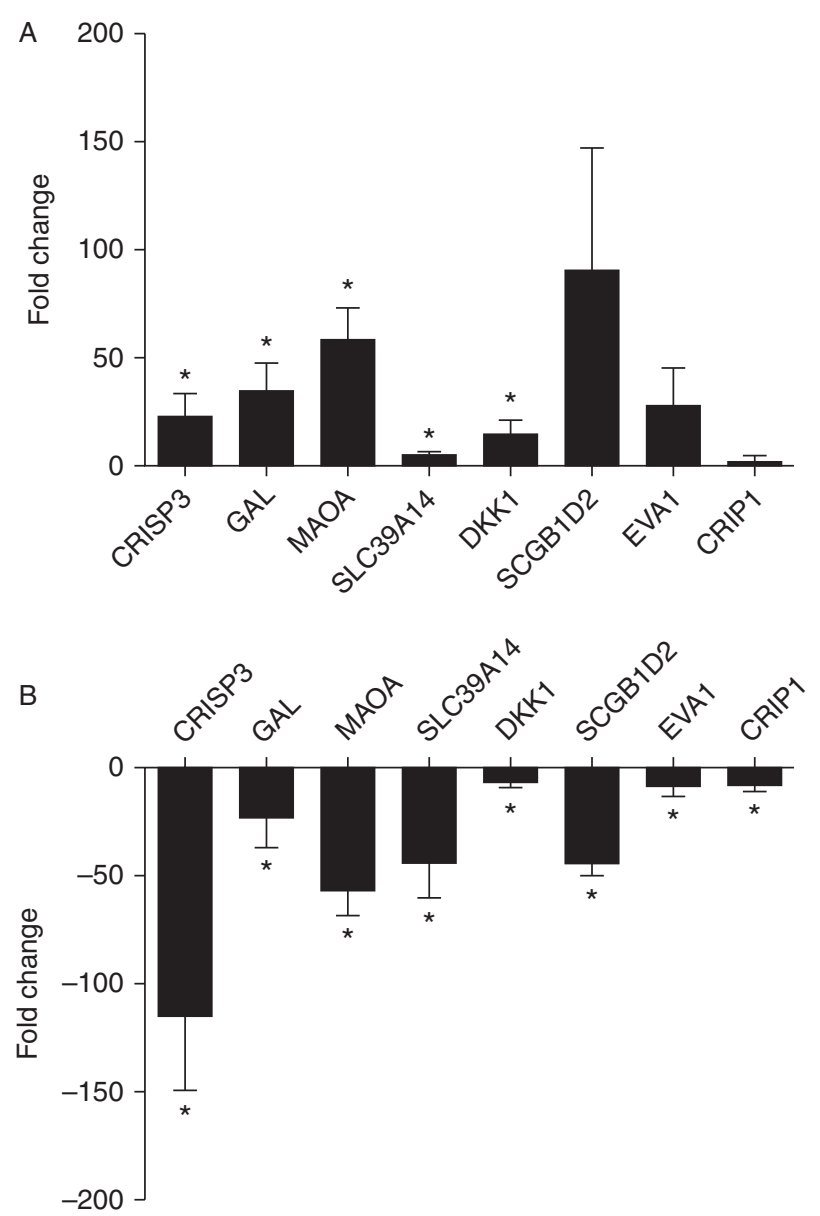

Figure 3 Validation of microarrays data by real-time RT-PCR. Real-time qPCR in endometrial samples was performed in pairwise comparisons of $\mathrm{LH}+2$ vs $\mathrm{LH}+7$ (A) and mifepristone vs placebo (B) after normalization to GAPDH. Each condition contains $n=7$ subject samples. Fold-change values were calculated from the $\Delta \Delta C T$ method for an endometrial gene expressed upon mifepristone vs placebo or $\mathrm{LH}+7$ vs $\mathrm{LH}+2$. Data are presented as mean \pm s.E.M. above $(\mathrm{A})$ or bellow (B) each gene and are plotted on the $y$-axis. $* P<0.05$, Wilcoxon two-sample paired signed rank test.

early secretory period (i.e. $\mathrm{LH}+2$ ). Under these circumstances, $\mathrm{P}_{4}$ action was antagonized from the beginning of the luteal phase and thus, avoiding the induction of early menses reflecting a lack of $\mathrm{P}_{4}$ action in mid-secretory endometrium. After 5 days of mifepristone administration is difficult to speculate about the proportion of PGRs that remain blocked in the endometrium since to our knowledge there is no report regarding this matter so far. The studies performed with mifepristone administration during the early luteal phase showed an out-of-phase endometrial development in spite of high circulating $\mathrm{P}_{4}$, suggesting a persistent block of the PGR (Swahn et al. 1990). The administration of mifepristone $(200 \mathrm{mg})$ in $\mathrm{LH}+2$ reaches a peak circulating level of $\sim 0.3-0.4 \mu \mathrm{mol} / \mathrm{l}$ within $2 \mathrm{~h}$ (Sarkar 2002) and is able to alter uterine gene expression in early pregnancy as early as $6 \mathrm{~h}$ after oral administration
(Critchley et al. 1996). However, considering that plasmatic half-life of mifepristone is $30 \mathrm{~h}$ (Sarkar 2002) and its concentration (as well as its metabolites that retain anti-progestin properties) is maintained at the micromolar level for at least $72 \mathrm{~h}$ (Heikinheimo et al. 2003) with detectable levels in circulation for 6-7 days (Sitruk-Ware \& Spitz 2003) we believe that most of the $\mathrm{P}_{4}$ effects are still abrogated in the endometrium on $\mathrm{LH}+7$. Thus, the endometrial phenotype observed 5 days after mifepristone administration results from the disruption of the events directly and indirectly driven by $\mathrm{P}_{4}$ from the early secretory phase until the window of implantation.

Mifepristone also has affinity and antagonistic effects on the glucocorticoid receptor (Bertagna et al. 1984) present in human endometrial stroma (Bamberger et al. 2001, Sitruk-Ware \& Spitz 2003). However for mifepristone to exert an anti-glucocorticoid effect, the dose that has to be administered is in the range of $5-20 \mathrm{mg} / \mathrm{kg}$ (Gaillard et al. 1984, Cadepond et al. 1997, Sitruk-Ware \& Spitz 2003, Johanssen \& Allolio 2007) which is a much higher dose than the used dose in the present study. Hence, we presume that the described changes on gene expression are mostly attributable to a blockade of $\mathrm{P}_{4}$ action without ruling out that some of them are driven by mifepristone regulation of the glucocorticoid receptor.

Our microarrays analysis identified 1915 transcripts differentially expressed in the transition from the prereceptive to receptive endometrium (i.e. from $\mathrm{LH}+2$ to $\mathrm{LH}+7$ ) in a spontaneous cycle. This number represents a $3.5 \%$ of the total number of analyzed transcripts. Other reports have using DNA microarrays technology have described a number of endometrial transcripts regulated during the receptive phase (highest $\mathrm{P}_{4}$ levels) compared with earlier stages of the secretory phase (low $\mathrm{P}_{4}$ levels) (Carson et al. 2002, Riesewijk et al. 2003, Mirkin et al. 2005, Talbi et al. 2006) or proliferative phase dominated by estrogen (Kao et al. 2002, Borthwick et al. 2003), suggesting a hormonal control of these genes. We contrasted our results with the reports afore mentioned. We found that the transcript for SPP1 was downregulated upon mifepristone while it appears up-regulated in the six other studies we compared our results in our reference group $(\mathrm{LH}+2 / \mathrm{LH}+7)$. Other six transcripts are regulated with mifepristone and are also regulated in the opposite direction in other five reports as well as in our reference group. Given the rather small number of coincident endometrial transcripts across the different studies reported during the window of implantation (Tapia et al. 2011); such concordance of transcript regulation with mifepristone validates our results.

When $\mathrm{P}_{4}$ action was blocked with mifepristone administration during the early luteal phase, the number of regulated transcripts during the receptive phase (2119, $\sim 3.9 \%$ ) was similar to the one that change during the window of implantation. When we compared the identity of such transcripts, we found that only a sub group of 777 were regulated in both comparisons. 
A rather small fraction of the differentially expressed genes upon mifepristone administration were shown to be associated with the acquisition of endometrial receptivity during a spontaneous cycle. To rule out the possibility that this proportion of overlapping transcripts was underestimated as a result of a significant amount of false-positive in each comparison, we performed the statistical analyses with a higher threshold (FDR $1 \%$, FC $\geq 4$ ) and found 594 and 470 regulated transcripts in the mifepristone and reference group $(\mathrm{LH}+2 / \mathrm{LH}+7)$ respectively. Only 130 transcripts (22\%) were common in both the groups and all of them displayed opposite regulatory direction between groups, except for three down-regulated transcripts in the mifepristone group, supporting our main finding. Endometrial receptivity results from the expression and repression of genes controlled by ovarian steroidal hormones and other factors; however it is well established that $\mathrm{P}_{4}$ is a critical determinant of endometrial function during the window of implantation (Rosario et al. 2003). Under this premise, it is surprising that only about a third of the genes that change its expression level at the moment of endometrial receptivity are also regulated under the action of mifepristone. A possible explanation to this is that not all the genes regulated during the window of implantation are necessarily involved in the acquisition of receptivity and it is possible that the gene regulation observed in a subgroup of transcripts is in response to other chemical messengers present during the secretory phase, independently of $\mathrm{P}_{4}$. The endometrium is exposed to important levels of estradiol and relaxin of ovarian origin that could influence and control endometrial gene expression. The function of estradiol during the secretory phase in humans is not clear and its role on acquisition of receptivity is controversial. Using the oocyte donation model in women without ovarian function, Younis et al. (1994) showed that estrogen privation during the secretory phase does not affect the development of endometrial morphology. On the other hand, other study using estrogen receptor antagonism with clomiphene starting 2 days after the LH peak in spontaneous cycles and maintained until an endometrial biopsy was taken on day 13 showed a consistently delayed histological dating (Fritz et al. 1987). In addition, endometrial tissue explants incubated with $\mathrm{P}_{4}$ or in combination with estradiol showed that the expression of a group of genes whose expression can be modulated only with $\mathrm{P}_{4}$, is sensitive to its exposure to estradiol suggesting that endometrial expression of some genes regulated by $\mathrm{P}_{4}$ are sensitive to the presence of estradiol (Dassen et al. 2007 b).

Circulating relaxin (RLX) levels rise during the luteal phase (Bond et al. 2004, Hayes 2004) and its detection in the endometrium during natural cycles coincide with the period of endometrial receptivity (Yki-Jarvinen et al. 1985) suggesting a role in the early events of embryo implantation. Several studies show that RLX exerts a wide range of effects on the human endometrium mediating differentiation, vascularization and immunomodulation in this tissue (Goldsmith \& Weiss 2009). Furthermore, RLX stimulates the secretion of several molecules in endometrial cells in vitro including prolactin (Telgmann \& Gellersen 1998), Insulin-like binding protein-1 (IGFBP1, Bell et al. 1991), glycodelin (Tseng et al. 1999) and vascular endothelial growth factor (VEGF; Unemori et al. 1999, Palejwala et al. 2002). The results obtained in the present study cannot distinguish between genes that are regulated by $\mathrm{P}_{4}$ and those whose transcript levels are regulated by the presence of estrogens, relaxin or other factors.

With regard to the functional clustering of regulated transcripts under mifepristone, the terms 'cell adhesion' and 'proliferation' were most consistent within the up-regulated transcripts. It has to be noted that the association of a particular function with a set of up- or down-regulated genes should not be interpreted as the function being regulated in the direction of the transcript level change. $\mathrm{P}_{4}$ has been shown to completely inhibit estrogen-induced epithelial cell proliferation and DNA synthesis (Das \& Martin 1973, Martin et al. 1973) which is in line with the functional clustering related with 'proliferation.' Moreover, a functional analysis of mifepristone responsive genes in Ishikawa cells identified a signaling pathway associated with adhesion and cellto-cell interactions (Tamm-Rosenstein et al. 2013), which is in line with the term 'cell adhesion' we found. In relation to the over-represented TBFS analysis in the promoter regions of endometrial genes regulated by mifepristone, it is interesting that the cognate sequence for PGR was not over represented, suggesting that the transcriptional regulation exerted by the PGR is presumably mostly indirect.

In conclusion, in this study we determined changes in endometrial gene expression during the receptive period associated with a pharmacologic blockade of $\mathrm{P}_{4}$ since $\mathrm{LH}+2$. Approximately a $37 \%$ of the genes regulated with mifepristone appear to be also associated with endometrial receptivity considering those whose transcript level also changed during the window of implantation (i.e. from $\mathrm{LH}+2$ to $\mathrm{LH}+7$ ). Interestingly, out of the total of coincident transcripts with differential expression, almost all of them $(96.8 \%)$ were found to be oppositely regulated, suggesting they are target of progesterone regulation and underlining their potential role in endowing the endometrium its receptive capacity. Additionally, more than 1000 transcripts whose endometrial levels change during period of receptivity see not to be regulated directly or indirectly by $\mathrm{P}_{4}$ considering that mifepristone did not interfere with this change. Further analysis should establish the cellular phenotypes and temporal dynamics involved in transcripts regulation as well as the function in the uterus of each gene identified in this study to elucidate the mechanisms regulating endometrial receptivity. 


\section{Declaration of interest}

The authors declare that there is no conflict of interest that could be perceived as prejudicing the impartiality of the research reported.

\section{Funding}

This work was supported by the Millenium Institute for Fundamental and Applied Biology (MIFAB), the National Fund for Scientific and Technological Development and the Government of Chile (FONDECYT grant numbers 11100443 and 1140614).

\section{Acknowledgements}

We thank all volunteers that participated in this study. We also thank Dr Fernando Gabler for the histopathological evaluations. Thanks also to Dr Ulises Urzua for his helpful guidance on microarrays analysis and Dr Kaori Koga for her suggestions critical comments for the manuscript.

\section{References}

Aerts S, Thijs G, Coessens B, Staes M, Moreau Y \& De Moor B 2003 Toucan: deciphering the cis-regulatory logic of coregulated genes. Nucleic Acid Research 31 1753-1764. (doi:10.1093/nar/gkg268)

Ashburner M, Ball CA, Blake JA, Botstein D, Butler H, Cherry JM, Davis AP, Dolinski K, Dwight SS, Eppig JT et al. 2000 Gene ontology: tool for the unification of biology. The Gene Ontology Consortium. Nature Genetics 25 25-29. (doi:10.1038/75556)

Bagchi IC, Cheon YP, Li Q \& Bagchi MK 2003 Progesterone receptorregulated gene networks in implantation. Frontiers in Bioscience 8 s852-s861. (doi:10.2741/1148)

Bamberger AM, Milde-Langosch K, Loning T \& Bamberger CM 2001 The glucocorticoid receptor is specifically expressed in the stromal compartment of the human endometrium. Journal of Clinical Endocrinology and Metabolism 86 5071-5074. (doi:10.1210/jcem.86.10.8101)

Baulieu EE 1989 Contragestion and other clinical applications of RU 486, an antiprogesterone at the receptor. Science 245 1351-1357. (doi:10.1126/science.2781282)

Bell SC, Jackson JA, Ashmore J, Zhu HH \& Tseng L 1991 Regulation of insulin-like growth factor-binding protein-1 synthesis and secretion by progestin and relaxin in long term cultures of human endometrial stromal cells. Journal of Clinical Endocrinology and Metabolism 72 1014-1024. (doi:10.1210/jcem-72-5-1014)

Bertagna X, Bertagna C, Luton JP, Husson JM \& Girard F 1984 The new steroid analog RU 486 inhibits glucocorticoid action in man. Journal of Clinical Endocrinology and Metabolism 59 25-28. (doi:10.1210/jcem-59-1-25)

Bond CP, Parry LJ, Samuel CS, Gehring HM, Lederman FL, Rogers PA \& Summers RJ 2004 Increased expression of the relaxin receptor (LGR7) in human endometrium during the secretory phase of the menstrual cycle. Journal of Clinical Endocrinology and Metabolism 89 3477-3485. (doi:10.1210/jc.2003-030798)

Borthwick JM, Charnock-Jones DS, Tom BD, Hull ML, Teirney R, Phillips SC \& Smith SK 2003 Determination of the transcript profile of human endometrium. Molecular Human Reproduction 9 19-33. (doi:10.1093/molehr/gag004)

Cadepond F, Ulmann A \& Baulieu EE 1997 RU486 (mifepristone): mechanisms of action and clinical uses. Annual Review Medicine 48 129-156. (doi:10.1146/annurev.med.48.1.129)

Carson DD, Lagow E, Thathiah A, Al-Shami R, Farach-Carson MC, Vernon M, Yuan L, Fritz MA \& Lessey B 2002 Changes in gene expression during the early to mid-luteal (receptive phase) transition in human endometrium detected by high-density microarray screening. Molecular Human Reproduction 8 871-879. (doi:10.1093/molehr/ 8.9.871)
Catalano RD, Yanaihara A, Evans AL, Rocha D, Prentice A, Saidi S, Print CG, Charnock-Jones DS, Sharkey AM \& Smith SK 2003 The effect of RU486 on the gene expression profile in an endometrial explant model. Molecular Human Reproduction 9 465-473. (doi:10.1093/ molehr/gag060)

Catalano RD, Critchley HO, Heikinheimo O, Baird DT, Hapangama D, Sherwin JR, Charnock-Jones DS, Smith SK \& Sharkey AM 2007 Mifepristone induced progesterone withdrawal reveals novel regulatory pathways in human endometrium. Molecular Human Reproduction 13 641-654. (doi:10.1093/molehr/gam021)

Chabbert-Buffet N, Meduri G, Bouchard P \& Spitz IM 2005 Selective progesterone receptor modulators and progesterone antagonists: mechanisms of action and clinical applications. Human Reproduction Update 11 293-307. (doi:10.1093/humupd/dmi002)

Chang JT \& Nevins JR 2006 GATHER: a systems approach to interpreting genomic signatures. Bioinformatics 22 2926-2933. (doi:10.1093/ bioinformatics/btl483)

Chauchereau A, Amazit L, Quesne M, Guiochon-Mantel A \& Milgrom E 2003 Sumoylation of the progesterone receptor and of the steroid receptor coactivator SRC-1. Journal of Biological Chemistry $\mathbf{2 7 8}$ 12335-12343. (doi:10.1074/jbc.M207148200)

Chien CH, Lai JN, Liao CF, Wang OY, Lu LM, Huang MI, Lee WF, Shie MC \& Chien EJ 2009 Mifepristone acts as progesterone antagonist of non-genomic responses but inhibits phytohemagglutinin-induced proliferation in human T cells. Human Reproduction 24 1968-1975. (doi:10. 1093/humrep/dep099)

Cole SW, Yan W, Galic Z, Arevalo J \& Zack JA 2005 Expression-based monitoring of transcription factor activity: the TELiS database. Bioinformatics 21 803-810. (doi:10.1093/bioinformatics/bti038)

Conneely OM \& Lydon JP 2000 Progesterone receptors in reproduction: functional impact of the A and B isoforms. Steroids 65 571-577. (doi:10.1016/S0039-128X(00)00115-X)

Critchley HO, Kelly RW, Lea RG, Drudy TA, Jones RL \& Baird DT 1996 Sex steroid regulation of leukocyte traffic in human decidua. Human Reproduction 11 2257-2262. (doi:10.1093/oxfordjournals.humrep. a019086)

Croxatto HB 2003 Mifepristone for luteal phase contraception. Contraception 68 483-488. (doi:10.1016/S0010-7824(03)00182-3)

Croxatto HB, Brache V, Pavez M, Cochon L, Forcelledo ML, Alvarez F, Massai R, Faundes A \& Salvatierra AM 2004 Pituitary-ovarian function following the standard levonorgestrel emergency contraceptive dose or a single $0.75-\mathrm{mg}$ dose given on the days preceding ovulation. Contraception 70 442-450. (doi:10.1016/j.contraception.2004.05.007)

Curtis SW, Clark J, Myers P \& Korach KS 1999 Disruption of estrogen signaling does not prevent progesterone action in the estrogen receptor alpha knockout mouse uterus. PNAS 96 3646-3651. (doi:10.1073/pnas. 96.7.3646)

Danielsson KG, Marions L \& Bygdeman M 2003 Effects of mifepristone on endometrial receptivity. Steroids 68 1069-1075. (doi:10.1016/S0039128X(03)00131-4)

Das RM \& Martin L 1973 Progesterone inhibition of mouse uterine epithelial proliferation. Journal of Endocrinology 59 205-206. (doi:10. 1677/joe.0.0590205)

Dasgupta S \& O'Malley BW 2014 Transcriptional coregulators: emerging roles of SRC family of coactivators in disease pathology. Journal of Molecular Endocrinology 53 R47-R59. (doi:10.1530/JME-14-0080)

Dassen H, Punyadeera C, Kamps R, Delvoux B, Van Langendonckt A, Donnez J, Husen B, Thole H, Dunselman G \& Groothuis P 2007a Estrogen metabolizing enzymes in endometrium and endometriosis. Human Reproduction 22 3148-3158. (doi:10.1093/humrep/dem310)

Dassen H, Punyadeera C, Kamps R, Klomp J, Dunselman G, Dijcks F, de Goeij A, Ederveen A \& Groothuis P 2007b Progesterone regulation of implantation-related genes: new insights into the role of oestrogen. Cellular and Molecular Life Sciences 64 1009-1032. (doi:10.1007/ s00018-007-6553-9)

Dennis G Jr, Sherman BT, Hosack DA, Yang J, Gao W, Lane HC \& Lempicki RA 2003 DAVID: database for annotation, visualization, and integrated discovery. Genome Biology 4 P3. (doi:10.1186/gb-2003-4-5-p3)

Dockery P, Ismail RM, Li TC, Warren MA \& Cooke ID 1997 The effect of a single dose of mifepristone (RU486) on the fine structure of the human endometrium during the early luteal phase. Human Reproduction 12 1778-1784. (doi:10.1093/humrep/12.8.1778) 
Evans GE, Martínez-Conejero JA, Phillipson GT, Simón C, McNoe LA, Sykes PH, Horcajadas JA, Lam EY, Print CG, Sin IL \& Evans JJ 2012 Gene and protein expression signature of endometrial glandular and stromal compartments during the window of implantation. Fertility and Sterility 9 1365-1373. (doi:10.1016/j.fertnstert.2012.03.007)

Evans GE, Martínez-Conejero JA, Phillipson GT, Sykes PH, Sin IL, Lam EY, Print CG, Horcajadas JA \& Evans JJ 2014 In the secretory endometria of women, luminal epithelia exhibit gene and protein expressions that differ from those of glandular epithelia. Fertility and Sterility 102 307-317. (doi:10.1016/j.fertnstert.2014.04.005)

Fritz MA, Westfahl PK \& Graham RL 1987 The effect of luteal phase estrogen antagonism on endometrial development and luteal function in women. Journal of Clinical Endocrinology and Metabolism 65 1006-1013. (doi:10.1210/jcem-65-5-1006)

Gaillard RC, Riondel A, Muller AF, Herrmann W \& Baulieu EE 1984 RU 486: a steroid with antiglucocorticosteroid activity that only disinhibits the human pituitary-adrenal system at a specific time of day. PNAS $\mathbf{8 1}$ 3879-3882. (doi:10.1073/pnas.81.12.3879)

Gellersen B, Brosens IA \& Brosens JJ 2007 Decidualization of the human endometrium: mechanisms, functions, and clinical perspectives. Seminars in Reproductive Medicine 25 445-453. (doi:10.1055/s-2007991042)

Gellersen B, Fernandes MS \& Brosens JJ 2009 Non-genomic progesterone actions in female reproduction. Human Reproduction Update $\mathbf{1 5}$ 119-138. (doi:10.1093/humupd/dmn044)

Gemzell-Danielsson K, Swahn ML, Svalander P \& Bygdeman M 1993 Early luteal phase treatment with mifepristone (RU 486) for fertility regulation. Human Reproduction 8 870-873.

Goldsmith LT \& Weiss G 2009 Relaxin in human pregnancy. Annals of the New York Academy of Sciences 1160 130-135. (doi:10.1111/j.17496632.2008.03800.x)

Graham JD \& Clarke CL 1997 Physiological action of progesterone in target tissues. Endocrine Reviews 18 502-519.

Gravanis A, Schaison G, George M, de Brux J, Satyaswaroop PG, Baulieu EE \& Robel P 1985 Endometrial and pituitary responses to the steroidal antiprogestin RU 486 in postmenopausal women. Journal of Clinical Endocrinology and Metabolism 60 156-163. (doi:10.1210/ jcem-60-1-156)

Hapangama DK, Brown A, Glasier AF \& Baird DT 2001 Feasibility of administering mifepristone as a once a month contraceptive pill. Human Reproduction 16 1145-1150. (doi:10.1093/humrep/16.6.1145)

Hayes ES 2004 Biology of primate relaxin: a paracrine signal in early pregnancy? Reproduction Biology and Endocrinology 2 36. (doi:10. 1186/1477-7827-2-36)

Heikinheimo O, Kekkonen R \& Lahteenmaki P 2003 The pharmacokinetics of mifepristone in humans reveal insights into differential mechanisms of antiprogestin action. Contraception 68 421-426. (doi:10.1016/S00107824(03)00077-5)

Hsueh AJ, Peck EJ Jr \& Clark JH 1975 Progesterone antagonism of the oestrogen receptor and oestrogen-induced uterine growth. Nature $\mathbf{2 5 4}$ 337-339. (doi:10.1038/254337a0)

Irizarry RA, Hobbs B, Collin F, Beazer-Barclay YD, Antonellis KJ, Scherf U \& Speed TP 2003 Exploration, normalization, and summaries of high density oligonucleotide array probe level data. Biostatistics 4 249-264. (doi:10.1093/biostatistics/4.2.249)

Jackson TA, Richer JK, Bain DL, Takimoto GS, Tung L \& Horwitz KB 1997 The partial agonist activity of antagonist-occupied steroid receptors is controlled by a novel hinge domain-binding coactivator L7/SPA and the corepressors N-CoR or SMRT. Molecular Endocrinology 11 693-705. (doi:10.1210/mend.11.6.0004)

Jeong JW, Lee KY, Han SJ, Aronow BJ, Lydon JP, O'Malley BW \& DeMayo FJ 2007 The p160 steroid receptor coactivator 2, SRC-2, regulates murine endometrial function and regulates progesterone-independent and -dependent gene expression. Endocrinology 148 4238-4250. (doi:10.1210/en.2007-0122)

Johanssen S \& Allolio B 2007 Mifepristone (RU 486) in Cushing's syndrome. European Journal of Endocrinology 157 561-569. (doi:10.1530/ EJE-07-0458)

Joliffe IT \& Morgan BJ 1992 Principal component analysis and exploratory factor analysis. Statistical Methods in Medical Research $\mathbf{1}$ 69-95. (doi:10.1177/096228029200100105)
Kanehisa M, Goto S, Hattori M, Aoki-Kinoshita KF, Itoh M, Kawashima S, Katayama T, Araki M \& Hirakawa M 2006 From genomics to chemical genomics: new developments in KEGG. Nucleic Acid Research 34 D354-D357. (doi:10.1093/nar/gkj102)

Kao LC, Tulac S, Lobo S, Imani B, Yang JP, Germeyer A, Osteen K, Taylor RN, Lessey BA \& Giudice LC 2002 Global gene profiling in human endometrium during the window of implantation. Endocrinology 143 2119-2138. (doi:10.1210/endo.143.6.8885)

Kemmeren P, van Berkum NL, Vilo J, Bijma T, Donders R, Brazma A \& Holstege FC 2002 Protein interaction verification and functional annotation by integrated analysis of genome-scale data. Molecular Cell 9 1133-1143. (doi:10.1016/S1097-2765(02)00531-2)

Kim JJ, Buzzio OL, Li S \& Lu Z 2005 Role of FOXO1A in the regulation of insulin-like growth factor-binding protein-1 in human endometrial cells: interaction with progesterone receptor. Biological Reproduction 73 833-839. (doi:10.1095/biolreprod.105.043182)

Kim TH, Lee DK, Franco HL, Lydon JP \& Jeong JW 2010 ERBB receptor feedback inhibitor 1 regulation of estrogen receptor activity is critical for uterine implantation in mice. Biological Reproduction 82 706-713. (doi:10.1095/biolreprod.109.081307)

Lalitkumar PG, Lalitkumar S, Meng CX, Stavreus-Evers A, Hambiliki F, Bentin-Ley U \& Gemzell-Danielsson K 2007 Mifepristone, but not levonorgestrel, inhibits human blastocyst attachment to an in vitro endometrial three-dimensional cell culture model. Human Reproduction 22 3031-3037. (doi:10.1093/humrep/dem297)

Lee K, Jeong J, Kwak I, Yu CT, Lanske B, Soegiarto DW, Toftgard R, Tsai MJ, Tsai S, Lydon JP et al. 2006 Indian hedgehog is a major mediator of progesterone signaling in the mouse uterus. Nature Genetics 38 1204-1209. (doi:10.1038/ng1874)

Liu JH, Garzo G, Morris S, Stuenkel C, Ulmann A \& Yen SS 1987 Disruption of follicular maturation and delay of ovulation after administration of the antiprogesterone RU486. Journal of Clinical Endocrinology and Metabolism 65 1135-1140. (doi:10.1210/jcem-65-6-1135)

Liu Z, Auboeuf D, Wong J, Chen JD, Tsai SY, Tsai MJ \& O'Malley BW 2002 Coactivator/corepressor ratios modulate PR-mediated transcription by the selective receptor modulator RU486. PNAS 99 7940-7944. (doi:10. 1073/pnas.122225699)

Livak K \& Schmittgen TD 2001 Analysis of Relative Gene Expression Data Using Real-Time Quantitative PCR and the $2^{-\Delta \Delta C_{T}}$ Method. Methods 25 402-408. (doi:10.1006/meth.2001.1262)

Maentausta O, Svalander P, Danielsson KG, Bygdeman M \& Vihko R 1993 The effects of an antiprogestin, mifepristone, and an antiestrogen, tamoxifen, on endometrial 17 beta-hydroxysteroid dehydrogenase and progestin and estrogen receptors during the luteal phase of the menstrual cycle: an immunohistochemical study. Journal of Clinical Endocrinology and Metabolism 77 913-918.

Martin L, Das RM \& Finn CA 1973 The inhibition by progesterone of uterine epithelial proliferation in the mouse. Journal of Endocrinology $\mathbf{5 7}$ 549-554. (doi:10.1677/joe.0.0570549)

Matsumoto H, Zhao X, Das SK, Hogan BL \& Dey SK 2002 Indian hedgehog as a progesterone-responsive factor mediating epithelial-mesenchymal interactions in the mouse uterus. Developmental Biology 245 280-290. (doi:10.1006/dbio.2002.0645)

Meyer ME, Pornon A, Ji JW, Bocquel MT, Chambon P \& Gronemeyer H 1990 Agonistic and antagonistic activities of RU486 on the functions of the human progesterone receptor. EMBO Journal 9 3923-3932.

Mirkin S, Arslan M, Churikov D, Corica A, Diaz JI, Williams S, Bocca S \& Oehninger S $2005 \mathrm{In}$ search of candidate genes critically expressed in the human endometrium during the window of implantation. Human Reproduction 20 2104-2117. (doi:10.1093/humrep/ dei051)

Misrahi M, Atger M, d'Auriol L, Loosfelt H, Meriel C, Fridlansky F, Guiochon-Mantel A, Galibert F \& Milgrom E 1987 Complete amino acid sequence of the human progesterone receptor deduced from cloned cDNA. Biochemical and Biophysical Research Communications 143 740-748. (doi:10.1016/0006-291X(87)91416-1)

Mukherjee A, Soyal SM, Fernandez-Valdivia R, Gehin M, Chambon P, Demayo FJ, Lydon JP \& O'Malley BW 2006 Steroid receptor coactivator 2 is critical for progesterone-dependent uterine function and mammary morphogenesis in the mouse. Molecular Cell Biology 26 6571-6583. (doi:10.1128/MCB.00654-06) 
Navot D, Scott RT, Droesch K, Veeck LL, Liu HC \& Rosenwaks Z 1991 The window of embryo transfer and the efficiency of human conception in vitro. Fertility and Sterility 55 114-118.

Noyes RW, Hertig AT \& Rock J 1975 Dating the endometrial biopsy. American Journal of Obstetrics and Gynecology 122 262-263.

O'Malley BW \& Tsai MJ 1992 Molecular pathways of steroid receptor action. Biological Reproduction 46 163-167. (doi:10.1095/biolreprod46.2.163)

Palejwala S, Tseng L, Wojtczuk A, Weiss G \& Goldsmith LT 2002 Relaxin gene and protein expression and its regulation of procollagenase and vascular endothelial growth factor in human endometrial cells. Biological Reproduction 66 1743-1748. (doi:10.1095/biolreprod66.6.1743)

Paria BC, Reese J, Das SK \& Dey SK 2002 Deciphering the cross-talk of implantation: advances and challenges. Science 296 2185-2188. (doi:10.1126/science.1071601)

Rhodes DR, Barrette TR, Rubin MA, Ghosh D \& Chinnaiyan AM 2002 Meta-analysis of microarrays: interstudy validation of gene expression profiles reveals pathway dysregulation in prostate cancer. Cancer Research 62 4427-4433.

Riesewijk A, Martin J, van Os R, Horcajadas JA, Polman J, Pellicer A, Mosselman S \& Simon C 2003 Gene expression profiling of human endometrial receptivity on days $\mathrm{LH}+2$ versus $\mathrm{LH}+7$ by microarray technology. Molecular Human Reproduction 9 253-264. (doi:10.1093/ molehr/gag037)

Rosario G, Sachdeva G, Okulicz WC, Ace CI, Katkam RR \& Puri CP 2003 Role of progesterone in structural and biochemical remodeling of endometrium. Frontiers in Bioscience 8 s924-s935. (doi:10.2741/1173)

Sarkar NN 2002 Mifepristone: bioavailability, pharmacokinetics and useeffectiveness. European Journal of Obstetrics, Gynecology, and Reproductive Biology 101 113-120. (doi:10.1016/S0301-2115(01)00522-X)

Schaison G, George M, Lestrat N, Reinberg A \& Baulieu EE 1985 Effects of the antiprogesterone steroid RU 486 during midluteal phase in normal women. Journal of Clinical Endocrinology and Metabolism 61 484-489. (doi:10.1210/jcem-61-3-484)

Shoupe D, Mishell DR Jr, Lahteenmaki P, Heikinheimo O, Birgerson L, Madkour H \& Spitz IM 1987 Effects of the antiprogesterone RU 486 in normal women. I. Single-dose administration in the midluteal phase. American Journal of Obstetrics and Gynecology 157 1415-1420. (doi:10.1016/S0002-9378(87)80235-1)

Simmen RC, Eason RR, McQuown JR, Linz AL, Kang TJ, Chatman L Jr, Till SR, Fujii-Kuriyama Y, Simmen FA \& Oh SP 2004 Subfertility, uterine hypoplasia, and partial progesterone resistance in mice lacking the Kruppel-like factor 9/basic transcription element-binding protein-1 (Bteb1) gene. Journal of Biological Chemistry 279 29286-29294. (doi:10.1074/jbc.M403139200)

Sitruk-Ware R \& Spitz IM 2003 Pharmacological properties of mifepristone: toxicology and safety in animal and human studies. Contraception $\mathbf{6 8}$ 409-420. (doi:10.1016/S0010-7824(03)00171-9)

Spitz IM 2003 Progesterone antagonists and progesterone receptor modulators: an overview. Steroids 68 981-993. (doi:10.1016/j.steroids. 2003.08.007)

Strowitzki T, Germeyer A, Popovici R \& von Wolff M 2006 The human endometrium as a fertility-determining factor. Human Reproduction Update 12 617-630. (doi:10.1093/humupd/dml033)

Swahn ML, Johannisson E, Daniore V, de la Torre B \& Bygdeman M 1988 The effect of RU486 administered during the proliferative and secretory phase of the cycle on the bleeding pattern, hormonal parameters and the endometrium. Human Reproduction 3 915-921.

Swahn ML, Bygdeman M, Cekan S, Xing S, Masironi B \& Johannisson E 1990 The effect of RU 486 administered during the early luteal phase on bleeding pattern, hormonal parameters and endometrium. Human Reproduction 5 402-408. (doi:10.1016/j.jsbmb.2015.06.010)

Szwarc MM, Lydon JP \& O'Malley BW 2015 Steroid receptor coactivators as therapeutic targets in the female reproductive system. Journal of Steroid Biochemistry and Molecular Biology 154 32-38. (doi:10.1016/j. jsbmb.2015.06.010)

Tabibzadeh S 1998 Molecular control of the implantation window. Human Reproduction Update 4 465-471. (doi:10.1093/humupd/4.5.465)

Takamoto N, Zhao B, Tsai SY \& DeMayo FJ 2002 Identification of Indian hedgehog as a progesterone-responsive gene in the murine uterus. Molecular Endocrinology 16 2338-2348. (doi:10.1210/me.2001-0154)
Talbi S, Hamilton AE, Vo KC, Tulac S, Overgaard MT, Dosiou C, Le Shay N, Nezhat CN, Kempson R, Lessey BA et al. 2006 Molecular phenotyping of human endometrium distinguishes menstrual cycle phases and underlying biological processes in normo-ovulatory women. Endocrinology 147 1097-1121. (doi:10.1210/en.2005-1076)

Tamm-Rosenstein K, Simm J, Suhorutshenko M, Salumets A \& Metsis M 2013 Changes in the transcriptome of the human endometrial Ishikawa cancer cell line induced by estrogen, progesterone, tamoxifen, and mifepristone (RU486) as detected by RNA-sequencing. PLoS Biology 8 e68907. (doi:10.1371/journal.pone.0068907)

Tapia A, Vilos C, Marin JC, Croxatto HB \& Devoto L 2011 Bioinformatic detection of E47, E2F1 and SREBP1 transcription factors as potential regulators of genes associated to acquisition of endometrial receptivity. Reproduction Biology and Endocrinology 9 14. (doi:10.1186/14777827-9-14)

Telgmann R \& Gellersen B 1998 Marker genes of decidualization: activation of the decidual prolactin gene. Human Reproduction Update 4 472-479. (doi:10.1093/humupd/4.5.472)

Torres MS, Ace CI \& Okulicz WC 2002 Assessment and application of laser microdissection for analysis of gene expression in the rhesus monkey endometrium. Biological Reproduction 67 1067-1072. (doi:10.1095/ biolreprod67.4.1067)

Tranguch S, Cheung-Flynn J, Daikoku T, Prapapanich V, Cox MB, Xie H, Wang H, Das SK, Smith DF \& Dey SK 2005 Cochaperone immunophilin FKBP52 is critical to uterine receptivity for embryo implantation. PNAS 102 14326-14331. (doi:10.1073/pnas.0505775102)

Tsai MJ \& O'Malley BW 1994 Molecular mechanisms of action of steroid/thyroid receptor superfamily members. Annual Review of Biochemistry 63 451-486. (doi:10.1146/annurev.bi.63.070194.002315)

Tseng L, Zhu HH, Mazella J, Koistinen H \& Seppala M 1999 Relaxin stimulates glycodelin mRNA and protein concentrations in human endometrial glandular epithelial cells. Molecular Human Reproduction 5 372-375. (doi:10.1093/molehr/5.4.372)

Tulac S, Overgaard MT, Hamilton AE, Jumbe NL, Suchanek E \& Giudice LC 2006 Dickkopf-1, an inhibitor of Wnt signaling, is regulated by progesterone in human endometrial stromal cells. Journal of Clinical Endocrinology and Metabolism 91 1453-1461. (doi:10.1210/jc.2005-0769)

Tung L, Mohamed MK, Hoeffler JP, Takimoto GS \& Horwitz KB 1993 Antagonist-occupied human progesterone B-receptors activate transcription without binding to progesterone response elements and are dominantly inhibited by A-receptors. Molecular Endocrinology 7 1256-1265. (doi:10.1210/mend.7.10.8123133)

Unemori EN, Erikson ME, Rocco SE, Sutherland KM, Parsell DA, Mak J \& Grove BH 1999 Relaxin stimulates expression of vascular endothelial growth factor in normal human endometrial cells in vitro and is associated with menometrorrhagia in women. Human Reproduction $\mathbf{1 4}$ 800-806. (doi:10.1093/humrep/14.3.800)

Wang H \& Dey SK 2006 Roadmap to embryo implantation: clues from mouse models. Nature Review Genetics 7 185-199. (doi:10.1038/nrg1808)

Wang H, Ma WG, Tejada L, Zhang H, Morrow JD, Das SK \& Dey SK 2004 Rescue of female infertility from the loss of cyclooxygenase-2 by compensatory up-regulation of cyclooxygenase- 1 is a function of genetic makeup. Journal of Biological Chemistry 279 10649-10658. (doi:10. 1074/jbc.M312203200)

Wilcox AJ, Baird DD \& Weinberg CR 1999 Time of implantation of the conceptus and loss of pregnancy. New England Journal of Medicine 340 1796-1799. (doi:10.1056/NEJM199906103402304)

Yki-Jarvinen H, Wahlstrom T \& Seppala M 1985 Human endometrium contains relaxin that is progesterone-dependent. Acta Obstetrica et Gynecologica Scandinavica 64 663-665. (doi:10.3109/00016348509 158210)

Younis JS, Ezra Y, Sherman Y, Simon A, Schenker JG \& Laufer N 1994 The effect of estradiol depletion during the luteal phase on endometrial development. Fertility and Sterility 62 103-107.

Received 28 September 2015

First decision 23 November 2015

Revised manuscript received 23 December 2015

Accepted 11 January 2016 